\title{
Does Trade Credit Boost Firm Performance?
}

\author{
Dongya Li \\ The University of Hong Kong \\ Yi Lu \\ The National University of Singapore \\ Travis $\mathrm{Ng}$ \\ The Chinese University of Hong Kong \\ Jun Yang \\ Chongqing University
}

April 10, 2015

\begin{abstract}
Some firms have achieved good performance in developing countries where the financial sector is far from established. One explanation in the literature is that these firms benefit from trade credit, a form of informal financing. Using a survey of firms in China conducted by the World Bank in early 2003, this paper examines whether trade credit indeed boosts firm performance. Our ordinary least squares results show that trade credit is significantly and positively correlated with firm performance. However, using the instrumental variable approach to address endogeneity, we find that the statistical significance disappears. The results are robust to a series of robustness checks, casting doubt on the claim that trade credit boosts firm performance.
\end{abstract}

Keywords: Trade Credit, Firm Performance, Informal Financing JEL Classifications: G3, L2, D2, O1 


\section{Does Trade Credit Boost Firm Performance?}

\section{Introduction}

Various studies have shown that strong financial institutions promote firm performance (e.g., Demirgüç-Kunt and Maksimovic, 1996, 1998; Beck, Demirgüç-Kunt and Maksimovic, 2004; Dyck and Zingales, 2004). ${ }^{1}$ However, in the past few decades in a number of developing economies where the financial sector is far from established, some firms have achieved good performance. These firms include private firms that are often discriminated against in their access to formal financing. Allen, Qian, and Qian (2005) and Ayyagari, Demirgüç-Kunt, and Maksimovic (2010) have documented cases like that in China. Since studies have also found that a large fraction of firms in the developing economies rely on informal financing such as trade credit (e.g., McMillan and Woodruff, 1999; Cull, $\mathrm{Xu}$, and $\mathrm{Zhu}, 2007)$, some point out that trade credit enables firms to achieve good performance (e.g., Ge and Qiu, 2007). Does trade credit really boost firm performance?

The literature gives three explanations of why trade credit boosts firm performance. First, trade credit is an important form of financing (Emery, 1987). It is especially so in the developing economies, where financial institutions are less developed and private firms are discriminated against in the access of formal financing, such as bank loans (e.g., Allen, Qian, and Qian, 2005; Ayyagari, Demirgüç-Kunt, and Maksimovic, 2010). Trade credit allows financially constrained firms to exploit profitable growth opportunities or to invest in efficiency-improving technologies, which in turn boosts firm performance (Demirgüç-Kunt and Maksimovic, 1998). Second, Fisman (2001) argue that firms with suppliers' trade credit are less prone to input shortages. As a result, their production is less likely to incur disruption. They can therefore manage their inventories and utilize their production capacities more efficiently. Third, building upon Smith (1987)'s ideas, Long, Malitz, and Ravid (1993) argue that trade credit can help guarantee input quality, thereby enhancing product quality. Firms may not be able to evaluate the quality of their inputs before using them. Trade credit allows them to start using the inputs and therefore better able to evaluate their quality before paying.

There remain, however, doubts on a causal impact of trade credit on firm performance. No suppliers would randomly grant trade credit to their clients. If trade credit

\footnotetext{
${ }^{1}$ There is a large body of literature on the impact of financial markets on economic performance and economic growth at the country level (e.g., Goldsmith, 1969; King and Levine, 1993; Levine and Zervos, 1998; Levine, 1998, 1999; Levine, Loayza, and Beck, 2000; La Porta, Lopez-de-Silanes, and Shleifer, 2002), and at the industry level (e.g., Rajan and Zingales, 1998; Wurgler, 2000; Cetorelli and Gambera, 2001; Claeseens and Laeven, 2005). Levine (2005) provides an excellent review of this literature.
} 
simply goes to better-performing firms, which is a finding of Petersen and Rajan (1997), we cannot conclude that trade credit boosts firm performance. Ge and Qiu (2007) find that private firms obtain more trade credit than state-owned enterprises in China, which is consistent with the view that more efficient firms get more trade credit. Omitting private ownership share in the regression, therefore, can result in a spurious positive correlation between trade credit and firm performance too. In addition, the aforementioned mechanisms may not work in developing economies. For example, firms worrying about input shortages (and hence disruption in production) may choose to work with reputable suppliers. Meanwhile, there exist other means to guarentee input quality (e.g., through enterprises associations and/or government agencies) that can in principle be cheaper than using trade credit.

There is a large literature investigating the various determinants of trade credit (e.g., Ferris, 1981; Mian and Smith, 1992; Biais and Gollier, 1997; Petersen and Rajan, 1997; McMillan and Woodruff, 1999; Ng, Smith, and Smith, 1999; and Cuñat, 2007). Few studies, however, examine whether trade credit boosts firm performance. To the best of our knowledge, only Fisman and Love (2003) examine the impact of trade credit on industry growth and find that industries with higher degrees of dependence on trade credit exhibit higher growth rates in countries with weaker financial institutions.

\subsection{Our empirical strategy}

We use a survey of firms in China conducted by the World Bank in early 2003 to examine, at the firm level rather than at the industry level, whether trade credit causally boosts firm performance.

Doing so requires the fact that firms are actually using trade credit, and reasonable variation of such usage across firms. Allen, Qian, and Qian (2005) find that lacking access to well-developed financial institutions, numerous Chinese firms indeed access finance through informal channels. Ayyagari, Demirgüç-Kunt, and Maksimovic (2010) show that the degree of development of formal financial institutions varies substantially across regions in China, resulting in differences in the financing patterns among firms across regions. In Section 2, we will show that the data exhibits these patterns.

We use three measures of firm performance: Labor Productivity (the logarithm of output per worker), return on assets $(R O A)$ (the return on fixed assets calculated at book value), and Firm Size (the logarithm of total sales). Our regressor of interest, Trade Credit, is measured as the average percentage of the two most important inputs that a firm buys without making an immediate cash payment. Section 2 details the data and the variables.

To see whether Trade Credit causally boosts firm performance, we regress our firm 
performance measures on Trade Credit, and the other determining factors of firm performance. The empirical challenge is that we only observe a subset of the latter (denoted $\mathbf{X}$ ) but not the remaining subset (denoted $\mathbf{W}$ ). Any $\mathbf{W}$ that we fail to control but are correlated with Trade Credit would bias our estimate. Specifically, since better performing firms are less likely to default. If the suppliers do observe some $\mathbf{W}$ unobservable to us that indicate the firm will perform well, and based on these indications, they extends more Trade Credit to the firm, then failing to control these $\mathbf{W}$ would bias up our estimate of the effect of Trade Credit on firm performance. This is perhaps a major reason why our ordinary-least-squares (OLS) estimations in Section 3.1 show that Trade Credit is positively and significantly correlated with all our firm performance measures.

To address this concern, we ask: Are there any factors independent of the firm performance that would be sufficient to justify the decision of extending more trade credit to the firm? If the suppliers are better able to enforce debt repayment from the firm, this alone appears a justification to extend more trade credit. Specifically,

Trade Credit $=f($ firm's ability to repay debt, suppliers' ability to enforce debt repayment),

where Trade Credit increases in both arguments of the function $f$. Therefore, if there are observables that indicate the suppliers are more able to enforce debt repayment, they would serve as reasonable instruments (IVs) of Trade Credit; they correlate with our endogenous variable Trade Credit (the relevance condition). If these IVs raise the suppliers' ability to enforce debt repayment and therefore increases Trade Credit without the need for the firm's ability to repay debt to simultaneously raise, then these IVs in principle would satisfy the exclusion restriction, i.e., they are not correlated with our dependent variable (firm performance) except through our endogenous variable (Trade Credit).

We find two such instruments; they concern two different channels through which the suppliers would enforce debt repayment. The first concerns the threat of cutting further inputs delivery in the case of a payment default. The measure, denoted Delay, is the average number of days the firm could take to obtain replacements if the main suppliers of its two major inputs fail to deliver. Everything else being equal, an increase in Delay makes a supplier's threat more credible, i.e., the threat that "if you do not pay me on time, I will not deliver further inputs to you" becomes more promising in enforcing debt repayment (McMillan and Woodruff, 1999). Consequently, Trade Credit increases with Delay.

The second concerns a reputation disciplinary mechanism through which the suppliers enforce debt repayment, namely, whether the suppliers can "bad word" the firm 
through friends and family networks in the case that the firm fails to make repayment on time. The measure, denoted Relationship, is the number of the firm's two most important inputs that are supplied by the firm owners' friends and relatives. McMillan and Woodruff (1999) argue that such a reputation disciplinary mechanism encourages the supplier to extend more trade credit. Consequently, Trade Credit increases with Relationship.

Our identifying assumption is: having taken the observable controls $(\mathbf{X})$ into account, knowing the instrument $Z$ (either Delay or Relationship) tells us nothing about the firm's other unobservables $(\mathbf{W})$. Formally, denote $Y$ as the outcome variable and $u$ as the error, which consists of the truly random noise $e$ and the unobservables $\mathbf{W}$. Our estimation model would be $Y=\alpha+\beta$ Trade Credit $+\mathbf{X}^{\prime} \boldsymbol{\Gamma}+u$, and the identifying assumption is $E(u \mid Z, \mathbf{X})=E(u \mid \mathbf{X})$.

This identifying assumption, therefore, would fail if the following situation happens. Having controlled for $\mathbf{X}$, there exist a $\mathbf{W}$ (unobserved factors correlated with firm performance) that correlates with the suppliers' Delay and Relationship. In other words, having controlled for $\mathbf{X}$, if Delay and Relationship do not help predict the omitted $\mathbf{W}$, our IV regressions are fine. If they do, our IV regressions are in trouble.

Not being able to observe $\mathbf{W}$ precludes us from entirely ruling out these possibilities. Therefore, other than the intuitive argument we give above, we mount our defense of the IVs by also looking into a number of statistical tests. First, the Hansen J statistic, which checks the satisfaction of the exclusion restriction in the over-identification scenario, cannot reject the null hypothesis that at least one of our IVs is exogenous. Second, regressing $Y$ directly on our $Z$ and $\mathbf{X}$ (i.e., reduced-form regressions), our IVs do not seem to significantly correlate with any firm performance measures. This tells us that our $Z$ are less likely to correlate with the omitted $\mathbf{W}$, thereby lending some confidence to our exclusion restriction. Third, we control explicitly for other potential channels through which the IVs might affect firm performance. Specifically, we consider five channel variables: the quality, specificity and delivery of inputs; the terms of trade credit; and the importance of the firm to its main suppliers.

Section 3.2 reports the first-stage results of the IV estimation; our IVs are positively and significantly correlated with Trade Credit. The second-stage results, however, consistently show that Trade Credit does not exert any significant impact on firm performance. Such an insignificance persists when we conduct the three tests suggested by Angrist and Pischke (2009): limited information maximum likelihood (LIML) estimations, reducedform regressions of our $Y$ on the IVs, and just-identified IV estimations, and when we exclude outliers, as well as only focus on a sub-sample of financially constrained firms. These results cast doubt on the claim that trade credit boosts firm performance. 


\section{Data and Variables}

Our data come from a survey of firms on the investment climate in China conducted jointly by the World Bank and the Enterprise Survey Organization of China in early 2003. For balanced representation, the Survey covers 18 cities from 5 regions in China: Northeast: Benxi, Changchun, Dalian, and Haerbin; Coastal: Hangzhou, Jiangmen, Shen- zhen, and Wenzhou; Central: Changsha, Nanchang, Wuhan, and Zhengzhou; Southwest: Chongqing, Guiyang, Kunming, and Nanning; and Northwest: Lanzhou and Xi'an. In each city, 100 or 150 firms are randomly sampled from nine manufacturing industries (garment and leather products, electronic equipment, electronic parts making, household electronics, auto and auto parts, food processing, chemical products and medicine, bio-tech products and Chinese medicine, and metallurgical products) and five service industries (transportation services, information technology, accounting and non-banking financial services, advertisement and marketing, and business services). The total number of firms surveyed is 2,400 . Since only manufacturing firms were required to answer the survey question regarding the use of trade credit, our final sample has 1,566 observations.

The Survey comprises two parts. One is a general questionnaire directed at senior management seeking information about the firm, innovation, product certification, marketing, relations with suppliers and customers, access to markets and technology, relations with government, labor, infrastructure, international trade, finance and taxation, and the GM and board of directors. The other questionnaire is directed at accountants and personnel managers, and covers ownership, various financial measures, and labor and training. The Survey is basically a cross-sectional dataset, with most of the variables measured in 2002; however, some of the financial variables, such as output, employment, and fixed assets, contain information from the past three years.

Again, the three measures of firm performance, Labor Productivity (measured as the logarithm of output per worker in 2002), ROA (measured as the return on fixed assets calculated at book value in 2002), and Firm Size (measured as the logarithm of total sales in 2002). Table 1a shows the summary statistics and the descriptions of all the variables.

Our regressor of interest, Trade Credit, is measured as the average percentage of the two most important inputs that a firm bought without making an immediate cash payment in 2002. The responses vary substantially across firms, with a mean value of 0.357 and a standard deviation of 0.373 . By regressing Trade Credit on city and industry dummies, we find a R-squared of 0.0837 , suggesting that $92 \%$ of the variation in Trade Credit comes from across-firms within the same industry/city. Therefore, our identification largely comes from across-firms, within industry/region variation. 
Previous studies use the ratio of account payable over total sales to measure the amount of trade credit that a firm obtains. However, due to data limitation, we only have information on the two most important inputs purchased by the firm. This raises the concern that we may not capture the entire amount of trade credit that firms get. To gauge the reliability of Trade Credit, we compare it with the corresponding trade credit measures reported in the literature. Cull, $\mathrm{Xu}$, and $\mathrm{Zhu}$ (2009) report that the ratio of trade credit over total sales in China ranges from $21.5 \%$ to $27.2 \%$ in the dataset of industrial firms collected by the National Bureau of Statistics of China for the period of 1998-2003. Ge and Qiu (2007) report a mean value of $27 \%$ trade credit over total sales from the enterprise survey conducted by the Chinese Academy of Social Sciences (CASS) in 2000. Further, in their study of inter-firm relationships in Vietnam, McMillan and Woodruff (1999) report an average of $30 \%$ of bills going unpaid after suppliers' delivery of goods.

Tables $1 \mathrm{~b}$ and $1 \mathrm{c}$ report the average of Trade Credit among firms by cities and industries, respectively. Firms in coastal areas (i.e., Shenzhen, Hangzhou, and Jiangmen) and in electronics manufacturing industries (i.e., household electronics, electronic equipment, and electronic parts making) use more trade credit, whereas those in inland areas (i.e., Zhengzhou, Lanzhou, and Changsha) use less.

We control for other factors (i.e., $\mathbf{X}$ ) that may affect firm performance but are unlikely to be determined by Trade Credit. Variables related to firm characteristics include Firm Age (measured as the logarithm of years of establishment by the end of 2002), Percentage of Private Ownership (the percentage of equities held by domestic private investors), Percentage of Foreign Ownership (the percentage of equities held by foreign investors), Bank Loan (a dummy variable indicating whether the firm has outstanding bank loans in 2002), and Government Representative on the Board (a dummy variable indicating whether there is a government representative on the board in 2002).

Note that our firm performance measures Firm Size measures the log of total firm sales in 2002, and Labor Productivity measures the log of output per worker in 2002. In our estimation, therefore, firm sales and employment size are explicitly modeled as outcomes of the regressor of interest. It is obvious, however, that firm performance necessarily depends on the firm's scale of operation. It is also likely that when extending trade credit to the firm, the suppliers also factor in the size of the firm. Not controlling firm size results in an omitted variable bias. It may also be plausible that our IVs correlate with the firm's scale of operation too, in which case our identifying assumption would fail if we do not control firm size. ${ }^{2}$ We can neither use the 2002 total sales nor the workers as they

\footnotetext{
${ }^{2}$ If firm size is a component of $\mathbf{W}$, our identifying assumption fails (i.e., $E(u \mid Z, \mathbf{X}) \neq E(u \mid \mathbf{X})$ ) if our instruments $Z$ somehow correlates with it.
} 
are outcomes of Trade Credit. We therefore resort to using Firm Size (Lagged) (measured as the logarithm of employment in 2001) as our controls. The employment size in 2001 tells us the scale of operation of the firm. Of course, Firm Size (Lagged) may correlate with our omitted variables $\mathbf{W}$ too. In that case, it too is endogenous and its estimated coefficient cannot be interpret as causal. This alone, however, does not fail our identifying assumption (i.e., the mean indepedence condition $E(u \mid Z, \mathbf{X})=E(u \mid \mathbf{X}))^{3}$

Variables related to GM characteristics include his/her human capital, denoted $E d u$ cation (years of schooling by the end of 2002), Years of Being GM (years of being GM by the end of 2002), and Deputy GM Before (a dummy variable indicating whether the GM was the firm's deputy GM before he/she became the GM); and his/her political capital: Government Cadre (a dummy variable indicating whether the GM was a government official before he/she became the GM), Party Membership (a dummy variable indicating whether the GM is a member of the Chinese Communist Party in 2002), and Government Appointment (a dummy variable indicating whether the GM was appointed by the government). Three variables are used to control for city/region differences: Logarithm of GDP per capita and Logarithm of Population, which measure the wealth and size of the cities, respectively; and region dummies, which control for all the differences across the five regions. ${ }^{4}$ Finally, industry dummies are included to account for the industry differences.

Our two IVs are again Delay and Relationship. Specifically, Delay is measured as the average number of days a firm could take to obtain replacements if the main suppliers of its two most important inputs failed to deliver in 2002), whereas Relationship is a category variable that takes values $0,0.5$, and 1 if none, one, and both of a firm's two most important inputs are supplied by friends or relatives of the firm owner in 2002, respectively. Section 3.3 further discusses the identification strategy of using the IVs. Table 2 reports the correlations among the key variables. The appendix lists the survey questions for the key variables.

\footnotetext{
${ }^{3}$ Stock and Watson (2012) show that estimating a consistent $\beta$ does not require the control variables $\mathbf{X}$ to be uncorrelated with the error term. It means that the estimated coefficients of these control variables do not have a causal interpretation.

${ }^{4}$ In our IV estimation, there is insufficient variation in the data if we control for the city fixed effects. We therefore resort to these alternative variables.
} 


\section{Empirical Analysis}

\subsection{The OLS Estimates}

We estimate the following equation:

$$
Y_{e i c}=\alpha+\beta \text { Trade } \text { Credit }_{e i c}+\mathbf{X}_{e i c}^{\prime} \boldsymbol{\Gamma}+u_{e i c}
$$

where $y_{\text {eic }}$ is the outcome variable for firm $e$ in industry $i$ and city $c$ (i.e. , Labor Productivity, $R O A$, and Firm Size), Trade Credit eic $_{\text {is }}$ the key explanatory variable, $\mathbf{X}_{\text {eic }}$ is a vector of control variables (i.e., firm characteristics, GM characteristics, city characteristics, region and industry dummies), and $u_{e i c}$ is the error term. Robust standard errors are clustered at the industry-city level. To consistently estimate $\beta$ requires the conditional mean independence condition. It means that conditional on $\mathbf{X}_{e i c}$, Trade Credit eic $_{\text {is }}$ incorrelated with the error term:

$$
E\left(u_{e i c} \mid \text { Trade Credit }{ }_{e i c}\right)=E\left(u_{e i c} \mid \mathbf{X}_{e i c}\right)
$$

Table 3 shows the results. Columns 1-3 show that Trade Credit is positively and significantly correlated with firm performance. ${ }^{5}$ The estimate implies that a one-standarddeviation increase in Trade Credit boosts Labor Productivity, ROA, and Firm Size by a 0.09, a 0.02 and a 0.08 standard deviations, respectively. Even if these estimates imply a causal relationship, the economic magnitude is rather small, casting doubts on the claim that trade credit matters.

\subsection{The IV Estimates}

Some firm performance factors $(\mathbf{W})$ we do not control go into the error $u$. If any of them correlate with Trade Credit, the conditional mean independence condition in (3) fails. We therefore use IVs. Specifically, we re-estimate equation (2) using the two-stage-leastsquares (TSLS) regression with the first-stage regression as follows:

$$
\text { Trade } \text { Credit }_{\text {eic }}=\gamma+\delta \mathrm{IV}_{e i c}+\mathbf{X}_{\text {eic }}^{\prime} \boldsymbol{\Theta}+\epsilon_{\text {eic }}
$$

where $\mathrm{IV}_{\text {eic }}$ are our two IVs: Delay and Relationship. As argued in Section 1.1, they are positively associated with our regressor of interest.

Increasing the IVs means the suppliers are better able to enforce debt repayment

\footnotetext{
${ }^{5}$ The results are similar with different subsets of controls too.
} 
from the firm, they should be positively associated with Trade Credit. This is because increasing Delay makes suppliers' threat of cutting further input delivery more credible. McMillan and Woodruff (1999) argue that when a firm is more locked into a relationship with its suppliers, the suppliers' threat of not delivering further inputs until the firm makes payment becomes a stronger disciplinary device. Hence, the suppliers are more willing to provide credit to the firm when it is difficult for their clients to find replacements in the market. ${ }^{6}$ Cuñat (2007) argue that suppliers increase the amount of trade credit to their clients when the transaction involves tailor-made inputs, learning by doing, or other sunk costs that generate a transaction surplus. These theoretical predictions are present among a panel of U.K. firms.

Increasing Relationship means the suppliers can more easily "bad mouth" the firm in case it fails to repay on time among friends and family networks. McMillan and Woodruff (1999) show that the suppliers are more likely to offer trade credit to their clients who belong to the same networks, such as families, friends, and business associations. These networks enable the use of an additional disciplinary device in enforcing debt repayment beyond threatening to stop further inputs delivery.

Table 4 shows the IV estimation results. The first-stage results reported in Panel B show that both Delay and Relationship have a positive and significant impact on Trade Credit. The second-stage results reported in Panel A show that Trade Credit no longer has a significant impact on any of our firm performance measures.

\subsubsection{The relevance condition}

Are our IVs relevant and strong? We look into the Anderson canonical correlation LR statistic and the Cragg-Donald Wald statistic in Panel C. In addition to the significant correlation between the IVs and the endogenous variable found in Panel B, these two statistics further confirm that they are relevant.

To check whether our IVs are strong instruments, we look into two statistics, the Shea partial R-square and the F-test of excluded instruments. The former, with values around 0.006, suggests that the correlation between our IVs and Trade Credit cannot be regard as very strong. Despite a statistical significance at the $5 \%$ level, the F-test of excluded

\footnotetext{
${ }^{6} \mathrm{~A}$ counterargument is that if the suppliers are extremely powerful (e.g., monopolize the input supply), then the suppliers may not have the incentives to extend trade credit to the firm. Fortunately, the Survey contains the information about how many suppliers a firm has used and how many suppliers are available in the market for the firm's two most important inputs, respectively, which allows us to check whether such extreme case happens in our setting. It is found that on average firms have used around 6-7 suppliers for their inputs production and there are around 100-160 suppliers available in the market. Meanwhile, we have conducted a robustness check by excluding firms using only 1 supplier for their inputs production and find the results remain qualitatively the same.
} 
instruments is around 3.8, which is below the critical value 10, the "safety zone" of a strong instrument argued by Staiger and Stock (1997). These two statistics raise the weak instruments concern. We therefore report three additional statistics, the Anderson-Rubin Wald test, the Stock-Wright LM S statistic, and the Finlay-Magnusson Wald test, which offer reliable statistical inferences in a weak instrument setting (Anderson and Rubin, 1949; Stock and Wright, 2000; Baum, Schaffer, and Stillman, 2003; Finlay and Magnusson, 2009). None of these three tests shows any statistical significance.

We conduct three other tests suggested by Angrist and Pischke (2009). First, we use the LIML estimation as it is approximately median-unbiased in the over-identification estimation and performs better than the two-stage-least square (TSLS) estimation when the IVs are potentially weak (e.g., Davidson and MacKinnon, 1993; Mariano, 2001; Stock, Yogo, and Wright, 2002; Hahn and Hausman, 2003; Flores-Lagunes, 2007). Panel D of Table 4 reports the LIML estimation results (only the estimated coefficients for Trade Credit are reported). ${ }^{7}$ The LIML estimates are similar to the TSLS estimates.

Second, we conduct reduced-form estimation: regressing our outcome variables on the IVs. As noted by Angrist and Krueger (2001) and Chernozhukov and Hansen (2008), if there is no correlation between our outcome variables and instrumental variables in these reduced-form regressions, then the endogenous variable probably has no impact on the outcome variables. As shown in Table 5, neither Relationship nor Delay is statistically significant.

Third, instead of using two IVs at the same time, we use one IV at a time. The just-identified TSLS estimation is median-unbiased, and the bias in the TSLS estimation increases in the number of IVs. Table 6 shows the results. These exercises all suggest that Trade Credit does not have a significant impact on our firm performance measures, and it is unlikely due to our IVs being weak.

\subsubsection{The exclusion restriction}

While our IVs concern the factors affecting the suppliers' propensity to extend trade credit, it remains impossible for us to completely rule out the possibility that the IVs affect the outcome variables through channels other than the endogenous variable. We address this concern with further statistical tests.

First, Panel C of Table 4 reports the Hansen J statistics; it is a standard test of the satisfaction of the exclusion restriction in the over-identification scenario. The Hansen J statistic cannot reject the null hypothesis that at least one of our instrumental variables is

\footnotetext{
${ }^{7}$ Henceforth, we also report the LIML estimation results whenever they are applicable.
} 
exogenous. The test has little power, however, if neither IV is exogenous. This concern brings us to the next two checks.

The first check brings us back to the reduced-form regressions of our outcome variables on our IVs in Table 5. Given that Trade Credit has no significant impact on firm performance, if our IVs have any significant impact on firm performance in the reducedform regressions, it would suggest that there are other channels through which the IVs affect firm performance. Table 5 shows that our IVs have no significant impact on firm performance in these reduced-form regressions, indirectly lending confidence on the exclusion restriction.

The second check involves explicitly controlling the potential channels other than the endogenous variable through which our IVs may affect our outcome variables. The results are similar for all three outcome variables. To save space, we only report in Table 7 the results for Labor Productivity. ${ }^{8}$

First, our IVs may affect firm performance through the quality of inputs. In the Survey, there is a question regarding the percentage of inputs with lower than expected quality, and a variable called Quality is constructed accordingly. We include Quality as an additional control variable in the TSLS estimation. Column 1 of Table 7 shows that Trade Credit remains insignificant.

Second, our IVs may affect firm performance through the specificity of inputs. In the Survey, there is a question asking whether the inputs are made to the firm's unique specifications, and a variable called Specificity is constructed accordingly. We include Specificity as an additional control variable in the TSLS estimation. Column 2 shows that Trade Credit remains insignificant.

Third, our IVs may affect firm performance through the delivery of inputs. In the Survey, there is a question regarding the percentage of sales lost in the previous year due to delivery delays from suppliers, and a variable called Delivery is constructed accordingly. Controlling Delivery as an additional control in column 3, we find that Trade Credit remains insignificant.

Fourth, our IVs may affect firm performance through the terms of trade credit, e.g., benefits accruing to the supplier in exchange for more generous credit terms. In the Survey, there is a question regarding the average number of days that the firm is allowed to pay back trade credit, which can be used to proxy for the trade credit terms. A variable called Credit Term is constructed accordingly. Column 4 shows that after controlling for Credit Term, Trade Credit remains insignificant.

Finally, our IVs may affect firm performance through the price of the inputs, because

\footnotetext{
${ }^{8}$ The results for $R O A$ and Firm size are available upon request.
} 
a close relationship between the firm and its suppliers may change the firm's bargaining power, thus resulting in a change in the input price. There is no question in the Survey directly measuring the prices of inputs. There is, however, a question allowing us to proxy for the firm's bargaining power vis-a-vis its suppliers: a question asking the firm whether it is the most important client of its main supplier, with an affirmative response reflecting a higher degree of bargaining power. A variable called Most Important Client is constructed accordingly. Controlling for Most Important Client, however, does not make Trade Credit significant, as shown in column 5.

Overall, the results suggest that trade credit is unlikely to have a causal impact on firm performance. ${ }^{9}$ Therefore, the significant results obtained in the OLS estimation are likely due to the endogeneity problems and should be interpreted with caution. ${ }^{10}$

\subsection{Discussion}

The insignificant results of our IV estimation suggest that the OLS estimates are driven by the endogeneity. Even if one is convinced that our IVs do work, she may still wonder if the insignificance comes from the specific features of our sampled firms. Are there outliers driving the results? Are they simply firms less likely to benefits from the particular ways trade credit usually benefits firms, as suggested by the literature? To what extent are the insignificance driven by the possibility that trade credit simply goes to faster-growing firms?

We first check if our insignificance results are driven by the outliers? To do so, we exclude observations whose concerned outcome variables having values larger than 3 standard deviation from the sample mean. ${ }^{11}$ The results reported in Table 8 show that Trade Credit continues to be not significant correlated with firm performance, suggesting that outliers are not driving our results.

Second, are we simply looking at firms that are not financially-constrained? If so, it is reasonable to expect that they would not benefit much from their suppliers' trade credit. We first divide firms into two groups: those that are and are not financially-constrained. To identify the sample of financially-constrained firms, we look into the Survey's question

\footnotetext{
${ }^{9}$ We have experimented with including all the five potential channel variables in one regression and find that Trade Credit remains statistically insignificant. However, our observations drop by about one third with the inclusion of all channel variables, which may contribute to the insignificance of Trade Credit. This result is available upon request.

${ }^{10}$ One may question whether the differences between the OLS and IV estimates come from sample attrition caused by missing values in the IVs. To address this concern, we report in Panel E the corresponding OLS estimates using the same sample as the IV estimates. We find similar OLS results, suggesting sample attrition is not the main reason behind the difference between the OLS and IV estimates.

${ }^{11}$ Excluding outliers that are identified using Hadi $(1992,1994)$ 's method results in similar results.
} 
that asks firms why they do not have bank loans. Two answers are possible: either the firm has never applied for a bank loan or it did but its application was rejected. We include those firms choosing the second answer in the sample. For firms choosing the first answer, there is a further question asking why they did not apply for a bank loan, with six possible answers: (i) there is no need for a bank loan; (ii) the application procedure is too cumbersome; (iii) collateral requirements are too stringent; (iv) the interest rate is too high; (v) there is corruption in the allocation of bank loans; and (vi) there is no expectation of approval. Answers (ii)-(vi) imply that the firm had the intention to apply for a bank loan but was deterred from doing so, whereas answer (i) suggests that the firm may be capitally abundant. We include firms choosing answers (ii)-(vi) in the sample of financially constrained firms. We further include firms with bank loans in the sample of financially constrained firms. ${ }^{12}$ Table 9 shows that we indeed have more than half of the firms in the sample that can be regarded as financially-constrained. Among these firms, the results suggest that Trade Credit continues to be insignificant. This is also true for those firms that are not financially-constrained.

Third, perhaps firms may alleviate their financial constraints by accessing credit from the buyer side. One may wonder if failing to control this variable would drive our results. In the Survey, there is a question regarding the percentage of cash payments by clients, and a variable called Buyer Credit is constructed accordingly. We include Buyer Credit as an additional control variable in Table 10. The estimated coefficient of Trade Credit remains insignificant, suggesting that access to buyer credit does not seem to matter to our results.

Fourth, Fisman (2001) suggests that trade credit can boost firm performance by enabling firms to resolve their problems of input shortage and the disruption in production with the supplier more effectively, resulting in better inventory management and capacity utilization. We look into this particular mechanism by examining firms' capacity utilization rates. The outcome variable Capacity Utilization comes from the Survey question "what was your plant's capacity utilization in 2002?" Table 11 shows that Trade Credit fails to be significant in the IV estimation even though the OLS estimates are significant. ${ }^{13}$ These results suggest that among our sample of firms, the disruption reduction mechanism are unlikely to be strong.

Fifth, Smith (1987) and Long, Malitz, and Ravid (1993) suggest that trade credit

\footnotetext{
${ }^{12}$ The results are similar if firms with bank loans are excluded from the sample of financially constrained firms.

${ }^{13}$ In the regression using outcome variable Capacity Utilization, we control for the degree of capacity utilization in the last year. And the results are similar without the control for the lagged degree of capacity utilization.
} 
boosts firm performance by helping the firm to better monitor the quality of the suppliers' inputs. By focusing on the subset of firms in the sample that are likely to face such a problem, we may find Trade Credit to significantly correlate with firm performance. However, it is challenging to identify those firms that face difficulties in monitoring suppliers' quality. The best we can do is to find a reasonable proxy. Specifically, the Survey contains a question asking whether the firm could find out if one of its main clients deceive another firm (for example, it does not pay even if it is capable of doing so). One potential merit of this proxy is that by using the information from the client side instead of the supplier side, we can avoid the issue that the revealed possibility of detecting bad suppliers is correlated with the choice of suppliers. We do, however, acknowledge that even if a firm cannot find out their deceiving clients' misbehavior, it is possible that they can find out who are the deceiving suppliers. To the extent that those firms facing difficulties in monitoring their clients also are more likely to face difficulties in monitoring their inputs' quality, the results shown in Table 12 for these sub-set (a little over 1/3) of firms offer some support to this monitoring effect. Specifically, among those firms not being able to find out their clients deceive others, Trade Credit becomes significant in all the OLS estimation, and becomes significant in the IV estimation for Labor Productivity and Firm Size but not for $R O A .{ }^{14}$ The corresponding IV estimates among those firms that are able to find out their clients deceive others shows no significance.

Finally, we have argued that suppliers extend more trade credit to firms with better growth potential. Such a reverse causality biases the OLS estimation. It is therefore a potential explanation behind the insignificance in the IV estimation. We examine this explanation by using the average annual growth rate of the firm sales in the past three years as a proxy for the firm's growth potential. Table 13 shows our OLS and IV estimation that includes this additional control variable. In the OLS results, the statistical significance of Trade Credit does not go away. We take the view that although the reverse causality would bias the OLS estimation, it is unlikely the only bias. In the IV results, however, Trade Credit continues to be insignificant. ${ }^{15}$

\footnotetext{
${ }^{14}$ We look at the Anderson- Rubin Wald test, Stock-Wright LM S statistic, and Finlay-Magnusson Wald test for the statistical inference because these statistics perform better when the IVs are weak instruments.

${ }^{15}$ We also experiment with the average growth rate in terms of both employment and the average labor productivity in the past three years as proxies for growth potential or good performance, and find similar results. Furthermore, controlling for the firm's growth potential in the IV estimation does not make the estimated coefficients of Trade Credit statistically significant.
} 


\section{Conclusion}

We find that in a sample of manufacturing firms in China, trade credit appears to significantly correlate with their performance. However, once we instrument the regressor of interest, Trade Credit, with IVs that arguably concern the ability of the suppliers in enforcing debt repayment, the significance of Trade Credit goes away. Our data comes from China rather than all the developing economies. Our measures are also not the best possible set one can imagine. As such, the results in the paper cannot entirely rule out a causal impact of trade credit on firm performance among all firms in the developing economies. Nevertheless, we would conclude that they cast doubt on the claim that trade credit causally boosts firm performance. A battery of robustness checks suggest that the results are unlikely driven by econometric errors.

Possible endogeneity at least can come from omitted variable biases and reverse causality, resulting in the differences between the OLS and the IV estimates. Nevertheless, in our sample, such differences are unlikely to be entirely due to the possibility that trade credit goes to better performing firms. Our evidence does not seem to suggest that trade credit helps firms to better manage their inventory and capacity. Whether the firms are getting a bank loans, and the amount of buyers' credit the firms get also do not seem to drive our results. We, however, find some limited support on the claim that if trade credit indeed boosts firm performance, it can come from the possibility that trade credit helps the firm to better monitor the quality of their supplier's inputs. 


\section{References}

1. Allen, Franklin, Jun Qian, and Meijun Qian. 2005. "Law, Finance, and Economic Growth in China." Journal of Financial Economics 77, 57-116.

2. Anderson, T.W. and H. Rubin. 1949. "Estimators of the Parameters of a Single Equation in a Complete Set of Stochastic Equations." Annals of Mathematical Statistics $21,570-582$.

3. Angrist, Joshua D. and Alan B. Krueger. 2001. "Instrumental Variables and the Search for Identification: From Supply and Demand to Natural Experiments." Journal of Economic Perspectives 15, 69-85.

4. Angrist, Joshua D. and Jorn-Steffen Pischke. 2009. Mostly Harmless Econometrics. Princeton, New Jersey: Princeton University Press.

5. Ayyagari, Meghana, Alis Demirgüç-Kunt, and Vojislav Maksimovic. 2010. "Formal versus Informal Finance: Evidence from China." Review of Financial Studies 23, 30483097.

6. Baum, Christopher F., Mark E. Schaffer, and Steven Stillman. 2003. "Enhanced Routines for Instrumental Variables/Generalized Method of Moments Estimation and Testing." Stata Journal 7, 465-506

7. Beck, Thorsten, Alis Demirgü ç-Kunt, and Vojislav Maksimovic.2004. "Financial and Legal Constraints to Firm Growth: Does Size Matther." Journal of Finance 60, 137-177.

8. Biais, Bruno and Christian Gollier. 1997. "Trade Credit and Credit Rationing." Review of Financial Studies 10, 903-937.

9. Cetorelli, Nicola and Michele Gambera. 2001. "Banking Structure, Financial Dependence and Growth: International Evidence from Industry Data." Journal of Finance $56,617-648$

10. Chernozhukov, Victor and Christian Hansen. 2008. "The Reduced Form: A Simple Approach to Inference with Weak Instruments." Economics Letters 100, 68-71.

11. Claessens, Stijn and Luc Laeven. 2005. "Financial Sector Competition, Financial Dependence, and Growth?" Journal of the European Economic Association 3, 179-207.

12. Cull, Robert and Lixin Colin Xu. 2005. "Institutions, Ownership, and Finance: the Determinant of Profit Reinvestment among Chinese Firms." Journal of Financial Economics 77, 117-146.

13. Cull, Robert, Lixin Colin Xu, and Tian Zhu. 2009. "Formal Finance and Trade Credit during China's Transition." Journal of Financial Intermediation 18, 173-192. 
14. Cuñat, Vicente. 2007. “Trade Credit: Suppliers as Debt Collectors and Insurance Providers." Review of Financial Studies 20, 491-527.

15. Davidon, Russell and James G. MacKinnon. 1993. Estimation and Inference in Econometrics. New York: Oxford University Press.

16. Demirgüç-Kunt, Alis and Vojislav Maksimovic. 1996. "Stock Market Development and Firm Financing Choices." World Bank Economic Review 10, 341-370.

17. Demirgüç-Kunt, Alis and Vojislav Maksimovic. 1998. "Law, Finance, and Firm Growth." Journal of Finance 53, 2107-2137.

18. Dyck, Alexander and Luigi Zingales. 2004. "Private Benefits of Control: An International Comparison." Journal of Finance 59, 537-600.

19. Emery, Gary W. 1987. "An Optimal Financial Response to Variable Demand." Journal of Financial and Quantitative Analysis 22, 209-225.

20. Ferris, Stephen J. 1981. "A Transactions Theory of Trade Credit Use." Quarterly Journal of Economics 96, 243-270.

21. Finlay, Keith and Leandro M. Magnusson. 2009. "Implementing Weak-Instrument Robust Tests for a General Class of Instrumental-Variable Models." Stata Journal 9, 398-421.

22. Fisman, Raymond. 2001. "Trade Credit and Productivity Efficiency in Developing Countries." World Development 29, 311-321.

23. Fisman, Raymond and Inessa Love. 2003. "Trade Credit, Financial Intermediary Development, and Industry Growth." Journal of Finance 58, 353-374.

24. Flores-Lagunes, Alfonso. 2007. "Finite Sample Evidence of IV Estimators under Weak Instruments." Journal of Applied Econometrics 22, 677-694.

25. Ge, Ying and Jiaping Qiu. 2007. "Financial Development, Bank Discrimination, and Trade Credit." Journal of Banking and Finance 31, 513-530.

26. Goldsmith, Raymond W. 1969. Financial Structure and Development. New Haven, CT: Yale University Press.

27. King, Robert G. and Ross Levine. 1993. "Finance and Growth: Schumpeter Might Be Right." Quarterly Journal of Economics 153, 717-738.

28. Hadi, Ali S. 1992. "Identifying Multiple Outliers in Multivariate Data." Journal of the Royal Statistical Society, Series (B) 54, 761-771.

29. Hadi, Ali S. 1994. "A Modification of a Method for the Detection of Outliers in Multivariate Samples." Journal of the Royal Statistical Society, Series (B) 56, 393-396. 
30. Hahn, Jinyong and Jerry Hausman. 2003. "Weak Instruments: Diagnosis and Cures in Empirical Econometrics." American Economic Review 93, 118-125.

31. La Porta, Rafael, Florencio Lopez-de-Silanes, and Andrei Shleifer. 2002. "Government Ownership of Banks.", Journal of Finance 57, 265-301.

32. Levine, Ross. 1998. "The Legal Environment, Banks, and Long-Run Economic Growth." Journal of Money, Credit, and Banking 30, 596-613.

33. Levine, Ross. 1999. "Law, Finance, and Economic Growth." Journal of Financial Intermediation 8, 36-67.

34. Levine, Ross. 2005. "Finance and Growth: Theory and Evidence." in Philippe Aghion and Steven Durlauf ed., Handbook of Economic Growth, The Netherlands: Elsevier Sci- ence.

35. Levine, Ross, Norman Loayza, and Thorsten Beck. 2000. "Finance and the Sources of Growth." Journal of Financial Economics 58, 261-300.

36. Levine, Ross and Sara Zervos. 1998. "Stock Markets, Banks, and Economic Growth." American Economic Review 88, 537-558.

37. Long, Michael S., Ileen B. Malitz, and S. Abraham Ravid. 1993. "Trade Credit, Quality Guarantees, and Product Marketability." Financial Management 22, 117-127.

38. Mariano, Roberto S. 2001. "Simultaneous Equation Model Estimators: Statistical Properties." in b. Baltagi ed., A companion to Theoretical Econometrics, Oxford, UK.

39. McMillan, John and Christopher Woodruff. 1999. "Interfirm Relationships and Informal Credit in Vietnam." Quarterly Journal of Economics 114, 1285-1320.

40. Mian, Shehzad L. and Clifford Smith. 1992. "Accounts Receivable Management Policy: Theory and Evidence." Journal of Finance 47, 169-200.

41. Ng, Chee K., Janet Kiholm Smith, and Richard Smith. 1999. "Evidence on the Determinants of Credit Terms used in Interfirm Trade." Journal of Finance 54, 11091129.

42. Petersen, Mitchell and Raghuram Rajan. 1997. "Trade Credit: Theories and Evidence." Review of Financial Studies 10, 661-691.

43. Rajan, Raghuram, G. and Luigi Zingales. 1998. "Financial Dependence and Growth." American Economic Review 88, 559-586.

44. Smith, Janet Kiholm. 1987. "Trade Credit and Informational Asymmetry." Journal of Finance 42, 863-869.

45. Staiger, Douglas and James H. Stock. 1997. "Instrumental Variables Regression with Weak Instruments." Econometrica 65, 557-586. 
46. Stock, James, Motohiro Yogo, and Jonathan H. Wright. 2002. "A Survey of Weak Instruments and Weak Identification in Generalized Method of Moments." Journal of Business and Economic Statistics 20, 518-529.

47. Stock, James and Mark M. Watson. 2012. Introduction to Econometrics 3rd Edition, Pearson, UK

48. Stock, James and Jonathan H. Wright. 2000. "GMM with Weak Identification." Econometrica 68, 1055-1096.

49. Wurgler, Jeffrey A. 2000. "Financial Markets and the Allocation of Capital." Journal of Financial Economics 58, 187-214. 
Table 1a: Summary Statistics and the description of the variables

\begin{tabular}{|c|c|c|c|c|c|c|}
\hline Variable & Obs & Mean & S.D. & Min & Max & Description \\
\hline Labor Productivity & 1557 & 4.322 & 1.562 & -3.989 & 11.893 & The logarithm of output per worker in 2002. \\
\hline ROA & 1544 & 0.106 & 2.727 & -49 & 83.64 & The return on fixed assets calculated at book value in 2002 . \\
\hline Firm Size & 1558 & 9.417 & 2.301 & 0.405 & 17.226 & $\begin{array}{l}\text { The logarithm of total sales in } 2002 \text {. } \\
\text { The average portion of a firm's two most important inputs that a firm bought without }\end{array}$ \\
\hline Trade Credit & 1368 & 0.357 & 0.373 & 0 & 1 & $\begin{array}{l}\text { making immediate cash payment in } 2002 \text {. } \\
\text { The average days it took for firms to obtain replacements if the main suppliers of the }\end{array}$ \\
\hline Delay & 1500 & 10.477 & 19.899 & 0 & 210 & $\begin{array}{l}\text { firms' two most important inputs failed to deliver in } 2002 \text {. } \\
\text { A category variable taking value } 0,0.5 \text {, and } 1 \text { when none of, one of, and both of a }\end{array}$ \\
\hline $\begin{array}{l}\text { Relationship } \\
\text { Percentage of Private }\end{array}$ & 1442 & 0.021 & 0.123 & 0 & 1 & firm's two most important inputs were supplied by relatives of the firm owner in 2002 . \\
\hline $\begin{array}{l}\text { Ownership } \\
\text { Percentage of }\end{array}$ & 1566 & 0.706 & 0.419 & 0 & 1 & The logarithm of employment in 2001. \\
\hline Foreign Ownership & 1566 & 0.107 & 0.265 & 0 & 1 & The logarithm of years of establishment by the end of 2002 . \\
\hline Firm Size (Lagged) & 1563 & 5.04 & 1.453 & 0 & 9.899 & The percentage of equity owned by domestic private investors. \\
\hline Firm Age & 1566 & 2.494 & 0.777 & 1.099 & 3.97 & The percentage of equity owned by foreign investors. \\
\hline $\begin{array}{l}\text { Bank Loan } \\
\text { Government }\end{array}$ & 1540 & 0.273 & 0.446 & 0 & 1 & A dummy variable indicating whether the firm had bank loans in 2002 . \\
\hline $\begin{array}{l}\text { Representative in the } \\
\text { Board }\end{array}$ & 1566 & 0.156 & 0.363 & 0 & 1 & $\begin{array}{l}\text { A dummy variable indicating whether there was government representative in the } \\
\text { board in } 2002 \text {. }\end{array}$ \\
\hline Education & 1553 & 14.361 & 2.503 & 0 & 18 & Years of schooling by the end of 2002. \\
\hline Years of Being GM & 1548 & 6.24 & 4.58 & 1 & 33 & $\begin{array}{l}\text { Years of being GM by the end of } 2002 \text {. } \\
\text { A dummy variable indicating whether the GM was firm's deputy GM before he }\end{array}$ \\
\hline Depute GM Before & 1566 & 0.277 & 0.448 & 0 & 1 & $\begin{array}{l}\text { became GM. } \\
\text { A dummy variable indicating whether the GM was a government official before he }\end{array}$ \\
\hline Government Cadre & 1566 & 0.035 & 0.184 & 0 & 1 & $\begin{array}{l}\text { became GM. } \\
\text { A dummy variable indicating whether the GM was a member of the Chinese }\end{array}$ \\
\hline $\begin{array}{l}\text { Party Membership } \\
\text { Government }\end{array}$ & 1566 & 0.658 & 0.475 & 0 & 1 & Communist Party in 2002. \\
\hline Appointment & 1566 & 0.239 & 0.427 & 0 & 1 & A dummy variable indicating whether the GM was appointed by the government. \\
\hline Quality & 1541 & 0.033 & 0.085 & 0 & 1 & $\begin{array}{l}\text { The percentage of supplies the firm purchased having lower than expected quality. } \\
\text { A dummy variable indicating whether the inputs were made to the firm's unique }\end{array}$ \\
\hline Specificity & 1444 & 0.068 & 0.221 & 0 & 1 & specification. \\
\hline Delivery & 1524 & 0.021 & 0.05 & 0 & 0.5 & The percentage of sales lost in the previous year due to delivery delays from suppliers. \\
\hline $\begin{array}{l}\text { Credit Term } \\
\text { Most Important } \\
\text { Client }\end{array}$ & 1011 & 21.707 & 43.427 & 0 & 720 & $\begin{array}{l}\text { The average days that the firm was required to pay back trade credit. } \\
\text { A dummy variable indicating whether the firm was the most important client of its } \\
\text { main supplier. }\end{array}$ \\
\hline
\end{tabular}


Table 1b: Trade Credit across Cities

\begin{tabular}{l|rr}
\hline \multicolumn{1}{c|}{ City } & Number & Trade Credit \\
\hline Shenzhen & 61 & 0.582 \\
Hangzhou & 64 & 0.527 \\
Jiangmen & 60 & 0.474 \\
Chongqing & 96 & 0.471 \\
Nanchang & 88 & 0.409 \\
Xian & 87 & 0.404 \\
Guiyang & 67 & 0.390 \\
Changchun & 87 & 0.388 \\
Nanning & 53 & 0.379 \\
Wenzhou & 47 & 0.370 \\
Dalian & 58 & 0.325 \\
Wuhan & 94 & 0.321 \\
Kunming & 89 & 0.283 \\
Haerbin & 93 & 0.266 \\
Changsha & 90 & 0.264 \\
Lanzhou & 74 & 0.247 \\
Benxi & 61 & 0.233 \\
Zhengzhou & 99 & 0.215 \\
\hline
\end{tabular}

Table 1c: Trade Credit across Industries

\begin{tabular}{l|rr}
\hline Industry & Number & Trade Credit \\
\hline Biotech Products and Chinese Medicine & 27 & 0.474 \\
Household Electronics & 55 & 0.420 \\
Electronic Equipment & 163 & 0.398 \\
Electronic Parts Making & 251 & 0.389 \\
Food Processing & 60 & 0.388 \\
Auto and Auto Parts & 318 & 0.385 \\
Chemical Products and Medicine & 54 & 0.331 \\
Garment and Leather Products & 310 & 0.304 \\
Metallurgical Products & 130 & 0.243 \\
\hline
\end{tabular}


Table 2: Correlation

\begin{tabular}{l|rrrrrr}
\hline & Labor Productivity & ROA & Firm Size & Trade Credit & Delay & Relationship \\
\hline Labor Productivity & 1.0000 & & & & & \\
ROA & 0.2022 & 1.0000 & & & & \\
Firm Size & 0.8075 & 0.1621 & 1.0000 & & \\
Trade Credit & 0.2231 & 0.0679 & 0.2570 & 1.0000 & & \\
Delay & 0.0992 & 0.0120 & 0.1290 & 0.0912 & 1.0000 & \\
Relationship & 0.0330 & 0.0119 & 0.0321 & 0.0820 & 0.0183 & 1.0000 \\
\hline
\end{tabular}


Table 3: OLS Estimates

Note: Robust standard errors, clustered at industry-city level, are presented in the bracket. *, **, ** represent significance at $10 \%, 5 \%, 1 \%$ level respectively.

\begin{tabular}{|c|c|c|c|}
\hline Dependent Variable & $\begin{array}{c}1 \\
\text { Labor Productivity }\end{array}$ & $\begin{array}{c}2 \\
\mathrm{ROA}\end{array}$ & $\begin{array}{c}3 \\
\text { Firm Size }\end{array}$ \\
\hline Trade Credit & $\begin{array}{c}0.384^{\star \star \star} \\
{[0.104]}\end{array}$ & $\begin{array}{l}0.167^{*} \\
{[0.091]}\end{array}$ & $\begin{array}{c}0.468^{\star \star \star} \\
{[0.105]}\end{array}$ \\
\hline \multicolumn{4}{|l|}{ Firm Characteristics } \\
\hline Firm Size (Lagged) & $\begin{array}{l}0.079^{\star \star} \\
{[0.031]}\end{array}$ & $\begin{array}{c}0.043 \\
{[0.059]}\end{array}$ & $\begin{array}{c}0.940^{\star \star *} \\
{[0.057]}\end{array}$ \\
\hline Firm Age & $\begin{array}{c}-0.405^{\star \star *} \\
{[0.062]}\end{array}$ & $\begin{array}{l}-0.059 \\
{[0.039]}\end{array}$ & $\begin{array}{c}-0.410^{\star \star \star} \\
{[0.067]}\end{array}$ \\
\hline Percentage of Private Ownership & $\begin{array}{c}0.141 \\
{[0.120]}\end{array}$ & $\begin{array}{c}0.465 \\
{[0.326]}\end{array}$ & $\begin{array}{c}0.154 \\
{[0.125]}\end{array}$ \\
\hline Percentage of Foreign Ownership & $\begin{array}{c}0.727^{\star \star \star} \\
{[0.160]}\end{array}$ & $\begin{array}{c}0.544 \\
{[0.339]}\end{array}$ & $\begin{array}{c}0.800^{* \star *} \\
{[0.179]}\end{array}$ \\
\hline Bank Loan & $\begin{array}{l}0.437^{* * *} \\
{[0.069]}\end{array}$ & $\begin{array}{c}0.081 \\
{[0.095]}\end{array}$ & $\begin{array}{c}0.579^{* * *} \\
{[0.088]}\end{array}$ \\
\hline Government Representative in the Board & $\begin{array}{l}0.384 * * \star \\
{[0.094]}\end{array}$ & $\begin{array}{l}0.279^{\star} \\
{[0.142]}\end{array}$ & $\begin{array}{c}0.478^{\star * \star} \\
{[0.116]}\end{array}$ \\
\hline $\begin{array}{l}\text { GM Characteristics } \\
\text { Human Capital }\end{array}$ & & & \\
\hline Education & $\begin{array}{l}0.063^{\star \star *} \\
{[0.019]}\end{array}$ & $\begin{array}{c}0.04 \\
{[0.024]}\end{array}$ & $\begin{array}{c}0.081^{\star * \star} \\
{[0.022]}\end{array}$ \\
\hline Years of Being GM & $\begin{array}{c}0.004 \\
{[0.008]}\end{array}$ & $\begin{array}{l}-0.002 \\
{[0.007]}\end{array}$ & $\begin{array}{c}0.007 \\
{[0.009]}\end{array}$ \\
\hline Deputy GM Before & $\begin{array}{l}-0.012 \\
{[0.075]}\end{array}$ & $\begin{array}{l}-0.177 \\
{[0.149]}\end{array}$ & $\begin{array}{c}0.004 \\
{[0.084]}\end{array}$ \\
\hline Political Capital & & & \\
\hline Government Cadre & $\begin{array}{c}0.198 \\
{[0.174]}\end{array}$ & $\begin{array}{c}0.005 \\
{[0.091]}\end{array}$ & $\begin{array}{c}0.228 \\
{[0.191]}\end{array}$ \\
\hline Party Membership & $\begin{array}{l}-0.030 \\
{[0.083]}\end{array}$ & $\begin{array}{l}-0.151^{*} \\
{[0.079]}\end{array}$ & $\begin{array}{l}-0.017 \\
{[0.092]}\end{array}$ \\
\hline Government Appointment & $\begin{array}{l}-0.211^{\star \star} \\
{[0.085]}\end{array}$ & $\begin{array}{c}0.185 \\
{[0.212]}\end{array}$ & $\begin{array}{c}-0.282^{\star * \star} \\
{[0.092]}\end{array}$ \\
\hline City Characteristics & & & \\
\hline Logarithm of GDP per Capita & $\begin{array}{c}0.489 * \star \star \\
{[0.093]}\end{array}$ & $\begin{array}{l}-0.081 \\
{[0.072]}\end{array}$ & $\begin{array}{c}0.520^{* \star *} \\
{[0.111]}\end{array}$ \\
\hline Logarithm of Population & $\begin{array}{c}0.375^{\star \star \star} \\
{[0.073]}\end{array}$ & $\begin{array}{l}-0.059 \\
{[0.087]}\end{array}$ & $\begin{array}{c}0.425^{\star \star \star} \\
{[0.082]}\end{array}$ \\
\hline $\begin{array}{l}\text { Region Dummy } \\
\text { Industry Characteristics }\end{array}$ & Yes & Yes & Yes \\
\hline Industry Dummy & Yes & Yes & Yes \\
\hline $\begin{array}{l}\text { Number of Observations } \\
\text { R-squared } \\
\text { F-test } \\
p \text {-value for F-test }\end{array}$ & $\begin{array}{c}1,326 \\
0.3748 \\
49.03 \\
0.0000\end{array}$ & $\begin{array}{c}1,313 \\
0.0485 \\
5.07 \\
0.0000\end{array}$ & $\begin{array}{l}1,326 \\
0.6634 \\
106.39 \\
0.0000\end{array}$ \\
\hline
\end{tabular}


Table 4: Main Results

Note: Robust standard errors, clustered at industry-city level, are presented in the round bracket. *, **, *** represent significance at $10 \%, 5 \%, 1 \%$ level respectively. In Panel D, the limited information maximum likelihood (LIML) regressions include the same control variables as those in the corresponding two-stage-least-squares (TSLS) regressions but results of these control variables are not reported to save space (available upon request).

\begin{tabular}{|c|c|c|c|}
\hline & 1 & 2 & 3 \\
\hline \multicolumn{4}{|c|}{ Panel A, Second Stage of TSLS } \\
\hline Dependent Variable & Labor Productivity & ROA & Firm Size \\
\hline Trade Credit & $\begin{array}{c}0.354 \\
{[1.503]}\end{array}$ & $\begin{array}{c}0.121 \\
{[1.167]}\end{array}$ & $\begin{array}{c}0.677 \\
{[1.575]}\end{array}$ \\
\hline \multicolumn{4}{|l|}{ Firm Characteristics } \\
\hline Firm Size & $\begin{array}{l}0.085^{\star \star} \\
{[0.042]}\end{array}$ & $\begin{array}{c}0.045 \\
{[0.051]}\end{array}$ & $\begin{array}{c}0.949 * \star \star \\
{[0.060]}\end{array}$ \\
\hline Firm Age & $\begin{array}{c}-0.383^{\star \star *} \\
{[0.062]}\end{array}$ & $\begin{array}{l}-0.056 \\
{[0.037]}\end{array}$ & $\begin{array}{c}-0.389^{* \star *} \\
{[0.069]}\end{array}$ \\
\hline Percentage of Private Ownership & $\begin{array}{c}0.136 \\
{[0.135]}\end{array}$ & $\begin{array}{c}0.473 \\
{[0.348]}\end{array}$ & $\begin{array}{c}0.160 \\
{[0.142]}\end{array}$ \\
\hline Percentage of Foreign Ownership & $\begin{array}{l}0.667^{\star \star} \\
{[0.276]}\end{array}$ & $\begin{array}{l}0.582^{*} \\
{[0.342]}\end{array}$ & $\begin{array}{l}0.685^{\star *} \\
{[0.282]}\end{array}$ \\
\hline Bank Loan & $\begin{array}{c}0.415^{\star \star \star} \\
{[0.073]}\end{array}$ & $\begin{array}{c}0.074 \\
{[0.101]}\end{array}$ & $\begin{array}{c}0.540 * \star * \\
{[0.085]}\end{array}$ \\
\hline Government Representative in the Board & $\begin{array}{l}0.394^{\star \star} \\
{[0.155]}\end{array}$ & $\begin{array}{c}0.290 \\
{[0.188]}\end{array}$ & $\begin{array}{c}0.476 * \star \star \\
{[0.173]}\end{array}$ \\
\hline \multicolumn{4}{|l|}{ GM Characteristics } \\
\hline Education & $\begin{array}{l}0.059^{* *} \\
{[0.025]}\end{array}$ & $\begin{array}{l}0.039^{*} \\
{[0.022]}\end{array}$ & $\begin{array}{c}0.075^{\star \star \star} \\
{[0.027]}\end{array}$ \\
\hline Years of Being GM & $\begin{array}{c}0.004 \\
{[0.009]}\end{array}$ & $\begin{array}{l}-0.002 \\
{[0.007]}\end{array}$ & $\begin{array}{c}0.009 \\
{[0.009]}\end{array}$ \\
\hline Deputy GM Before & $\begin{array}{l}-0.014 \\
{[0.090]}\end{array}$ & $\begin{array}{l}-0.176 \\
{[0.123]}\end{array}$ & $\begin{array}{c}0.017 \\
{[0.102]}\end{array}$ \\
\hline \multicolumn{4}{|l|}{ Political Capital } \\
\hline Government Cadre & $\begin{array}{c}0.104 \\
{[0.179]}\end{array}$ & $\begin{array}{l}-0.004 \\
{[0.082]}\end{array}$ & $\begin{array}{c}0.168 \\
{[0.201]}\end{array}$ \\
\hline Party Membership & $\begin{array}{l}-0.047 \\
{[0.093]}\end{array}$ & $\begin{array}{c}-0.163^{\star \star} \\
{[0.083]}\end{array}$ & $\begin{array}{l}-0.042 \\
{[0.101]}\end{array}$ \\
\hline Government Appointment & $\begin{array}{c}-0.232^{\star *} \\
{[0.100]}\end{array}$ & $\begin{array}{c}0.191 \\
{[0.194]}\end{array}$ & $\begin{array}{c}-0.303^{\star \star *} \\
{[0.110]}\end{array}$ \\
\hline \multicolumn{4}{|l|}{ City Characteristics } \\
\hline Logarithm of GDP per Capita & $\begin{array}{l}0.496^{\star * *} \\
{[0.098]}\end{array}$ & $\begin{array}{l}-0.088 \\
{[0.075]}\end{array}$ & $\begin{array}{c}0.523^{\star \star *} \\
{[0.118]}\end{array}$ \\
\hline Logarithm of Population & $\begin{array}{l}0.391 * \star \star \\
{[0.079]}\end{array}$ & $\begin{array}{c}-0.059 \\
{[0.094]}\end{array}$ & $\begin{array}{c}0.440^{* * *} \\
{[0.087]}\end{array}$ \\
\hline \multirow{2}{*}{$\begin{array}{l}\text { Region Dummy } \\
\text { Industry Characteristics } \\
\text { Industry Dummy }\end{array}$} & Yes & Yes & Yes \\
\hline & Yes & Yes & Yes \\
\hline \multicolumn{4}{|c|}{ Panel B, First Stage of TSLS: Dependent Variable is Trade Credit } \\
\hline Delay & $\begin{array}{c}0.001^{*} \\
{[0.001]}\end{array}$ & $\begin{array}{l}0.001^{\star} \\
{[0.001]}\end{array}$ & $\begin{array}{l}0.001^{*} \\
{[0.001]}\end{array}$ \\
\hline Relationship & $0.186^{\star \star}$ & $0.183^{\star \star}$ & $0.186^{\star \star}$ \\
\hline
\end{tabular}


Firm Characteristics

Firm Size

Firm Age

Percentage of Private Ownership

Percentage of Foreign Ownership

Bank Loan

Government Representative in the Board

GM Characteristics

Human Capital

Education

Years of Being GM

Deputy GM Before

Political Capital

Government Cadre

Party Membership

Government Appointment

City Characteristics

Logarithm of GDP per Capita

Logarithm of Population

Region Dummy

Industry Characteristics

Industry Dummy
[0.090]

0.014

[0.009]

$-0.007$

[0.016]

$-0.029$

[0.025]

$0.125^{\star *}$

[0.055]

0.015

[0.021]

$0.083^{\star \star}$

[0.037]

0.010 **

[0.004]

$-0.002$

[0.002]

$-0.040^{*}$

[0.022]

$-0.020$

[0.065]

$-0.023$

[0.024]

0.034

[0.027]

0.020

[0.031]

0.006

[0.020]

Yes

Yes

Panel C, Various First-Stage Statistic Tests

Relevance Test

Anderson Canonical Correlations LR Statistic

Cragg-Donald Wald Statistic

Weak Instrument Test

Shea Partial

F Test of Excluded Instrument

Anderson-Rubin Wald test

Stock-Wright LM S statistic

Finlay-Magnusson Wald test

Overidentification Test

$p$-value for Hansen J statistic
[0.090] [0.090]

$0.014 \quad 0.014$

[0.009] [0.009]

$-0.007 \quad-0.007$

[0.016] [0.016]

$-0.024 \quad-0.029$

[0.024] [0.025]

$0.128^{\star \star} \quad 0.125^{\star \star}$

[0.054] [0.055]

$0.012 \quad 0.015$

[0.021] [0.021]

$0.081^{\star \star} \quad 0.083^{\star *}$

[0.036] [0.037]

0.010 ** $\quad 0.010$ **

[0.004] [0.004]

$-0.002 \quad-0.002$

[0.002] [0.002]

$-0.045^{\star *} \quad-0.040^{*}$

[0.022] [0.022]

$\begin{array}{ll}-0.031 & -0.020\end{array}$

[0.064] [0.065]

$-0.020 \quad-0.023$

[0.023] [0.024]

$0.038 \quad 0.034$

[0.028] [0.027]

$0.016 \quad 0.020$

[0.031] [0.031]

$0.007 \quad 0.006$

[0.020] [0.020]

Yes Yes

Yes Yes

\begin{tabular}{ccc}
{$[7.04]^{\star \star}$} & {$[6.83]^{\star \star}$} & {$[6.31]^{\star \star}$} \\
{$[7.92]^{\star \star}$} & {$[7.66]^{\star \star}$} & {$[7.25]^{\star \star}$} \\
0.0060 & 0.0058 & 0.0060 \\
{$[3.85]^{\star \star}$} & {$[3.74]^{\star \star}$} & {$[3.85]^{\star \star}$} \\
{$[0.18]$} & {$[0.01]$} & {$[0.27]$} \\
{$[0.36]$} & {$[0.03]$} & {$[0.58]$} \\
{$[0.06]$} & {$[0.01]$} & {$[0.18]$} \\
& & \\
0.5649 & 0.9974 & 0.5263 \\
\hline
\end{tabular}

Panel D, Second Stage of LIML 


\begin{tabular}{|c|c|c|c|}
\hline Trade Credit & $\begin{array}{c}0.352 \\
{[1.598]}\end{array}$ & $\begin{array}{c}0.121 \\
{[1.167]}\end{array}$ & $\begin{array}{c}0.693 \\
{[1.688]}\end{array}$ \\
\hline \multicolumn{4}{|c|}{ Panel E, OLS } \\
\hline Trade Credit & $\begin{array}{c}0.385^{\star \star *} \\
{[0.113]}\end{array}$ & $\begin{array}{l}0.177^{*} \\
{[0.094]}\end{array}$ & $\begin{array}{c}0.455^{\star \star \star} \\
{[0.113]}\end{array}$ \\
\hline Number of Observations & 1,265 & 1,252 & 1,265 \\
\hline
\end{tabular}


Table 5: Main Results, Counter Check I: Reduced-Form Regressions

\begin{tabular}{|c|c|c|c|}
\hline Dependent Variable & $\begin{array}{c}1 \\
\text { Labor Productivity }\end{array}$ & $\begin{array}{c}2 \\
\mathrm{ROA}\end{array}$ & $\begin{array}{c}3 \\
\text { Firm Size }\end{array}$ \\
\hline Delay & $\begin{array}{c}0.001 \\
{[0.002]}\end{array}$ & $\begin{array}{c}0.000 \\
{[0.002]}\end{array}$ & $\begin{array}{c}0.002 \\
{[0.002]}\end{array}$ \\
\hline Relationship & $\begin{array}{l}-0.054 \\
{[0.353]}\end{array}$ & $\begin{array}{c}0.023 \\
{[0.143]}\end{array}$ & $\begin{array}{l}-0.014 \\
{[0.382]}\end{array}$ \\
\hline $\begin{array}{l}\text { Included Control Variables } \\
\text { Firm Characteristics }\end{array}$ & Yes & Yes & Yes \\
\hline GM Characteristics & Yes & Yes & Yes \\
\hline City Characteristics & Yes & Yes & Yes \\
\hline Industry Characteristics & Yes & Yes & Yes \\
\hline Number of Observations & 1,265 & 1,252 & 1,265 \\
\hline R-squared & 0.3373 & 0.0382 & 0.6592 \\
\hline F-test & 27.18 & 3.88 & 92.49 \\
\hline $\mathrm{p}$-value for F-test & 0.0000 & 0.0000 & 0.0000 \\
\hline
\end{tabular}


Table 6: Main Results, Counter Check II: Just-identified TSLS Estimation

Note: Robust standard errors, clustered at industry-city level, are presented in the round bracket. * ${ }^{* *},{ }^{* *}$ represent significance at $10 \%, 5 \%, 1 \%$ level respectively.

\begin{tabular}{|c|c|c|c|c|c|c|}
\hline & 1 & 2 & 3 & 4 & 5 & 6 \\
\hline \multicolumn{7}{|c|}{ Panel A, Second Stage of TSLS } \\
\hline Dependent Variable & \multicolumn{2}{|c|}{ Labor Productivity } & \multicolumn{2}{|c|}{ ROA } & \multicolumn{2}{|c|}{ Firm Size } \\
\hline Trade Credit & $\begin{array}{c}1.319 \\
{[2.272]}\end{array}$ & $\begin{array}{c}-0.178 \\
{[1.754]}\end{array}$ & $\begin{array}{c}0.158 \\
{[2.037]}\end{array}$ & $\begin{array}{c}0.102 \\
{[0.705]}\end{array}$ & $\begin{array}{c}2.384 \\
{[2.569]}\end{array}$ & $\begin{array}{c}0.039 \\
{[1.890]}\end{array}$ \\
\hline \multicolumn{7}{|c|}{ Panel B, First Stage of TSLS: Dependent Variable is Trade Credit } \\
\hline Delay & $\begin{array}{c}0.001^{*} \\
{[0.001]}\end{array}$ & & $\begin{array}{c}0.001^{*} \\
{[0.001]}\end{array}$ & & $\begin{array}{l}0.001 * \\
{[0.001]}\end{array}$ & \\
\hline Relationship & & $\begin{array}{l}0.197^{* *} \\
{[0.089]}\end{array}$ & & $\begin{array}{l}0.194^{\star \star} \\
{[0.088]}\end{array}$ & & $\begin{array}{l}0.197^{\star *} \\
{[0.089]}\end{array}$ \\
\hline \multicolumn{7}{|c|}{ Panel C, Various First-Stage Statistics Tests } \\
\hline \multicolumn{7}{|l|}{ Relevance Test } \\
\hline Anderson Canonical Correlations LR Statistic & {$[2.83]^{\star}$} & {$[5.13]^{\star \star}$} & {$[2.74]^{\star}$} & {$[5.03]^{\star \star}$} & {$[2.68]^{\star}$} & {$[4.72]^{\star \star}$} \\
\hline \multicolumn{7}{|l|}{ Weak Instrument Test } \\
\hline Shea Partial & 0.0025 & 0.0041 & 0.0025 & 0.0040 & 0.0025 & 0.0041 \\
\hline F Test of Excluded Instrument & {$[3.13]^{\star}$} & {$[4.92]^{\star \star}$} & {$[3.02]^{\star}$} & {$[4.83]^{\star \star}$} & {$[3.13]^{\star}$} & {$[4.92]^{\star \star}$} \\
\hline Anderson-Rubin Wald test & {$[0.33]$} & {$[0.01]$} & {$[0.01]$} & {$[0.02]$} & [0.92] & {$[0.00]$} \\
\hline Stock-Wright LM S statistic & {$[0.34]$} & {$[0.01]$} & {$[0.01]$} & {$[0.02]$} & [0.98] & {$[0.00]$} \\
\hline Finlay-Magnusson Wald test & {$[0.34]$} & {$[0.01]$} & {$[0.01]$} & {$[0.02]$} & {$[0.86]$} & {$[0.00]$} \\
\hline \multicolumn{7}{|c|}{ Panel D, OLS } \\
\hline Trade Credit & $\begin{array}{c}0.401^{\star * *} \\
{[0.108]}\end{array}$ & $\begin{array}{c}0.376^{\star \star \star} \\
{[0.109]}\end{array}$ & $\begin{array}{c}0.181^{*} \\
{[0.094]}\end{array}$ & $\begin{array}{c}0.165^{\star} \\
{[0.092]}\end{array}$ & $\begin{array}{c}0.484^{\star \star *} \\
{[0.109]}\end{array}$ & $\begin{array}{c}0.448^{\star * *} \\
{[0.109]}\end{array}$ \\
\hline Firm Characteristics & Yes & Yes & Yes & Yes & Yes & Yes \\
\hline GM Characteristics & Yes & Yes & Yes & Yes & Yes & Yes \\
\hline City Characteristics & Yes & Yes & Yes & Yes & Yes & Yes \\
\hline Industry Characteristics & Yes & Yes & Yes & Yes & Yes & Yes \\
\hline Number of Observations & 1,291 & 1,296 & 1,278 & 1,283 & 1,291 & 1,296 \\
\hline
\end{tabular}


Table 7: Main Results, Counter Check III: With More Controls

Note: Robust standard errors, clustered at industry-city level, are presented in the round bracket. *, **, *** represent significance at $10 \%, 5 \%, 1 \%$ level respectively.

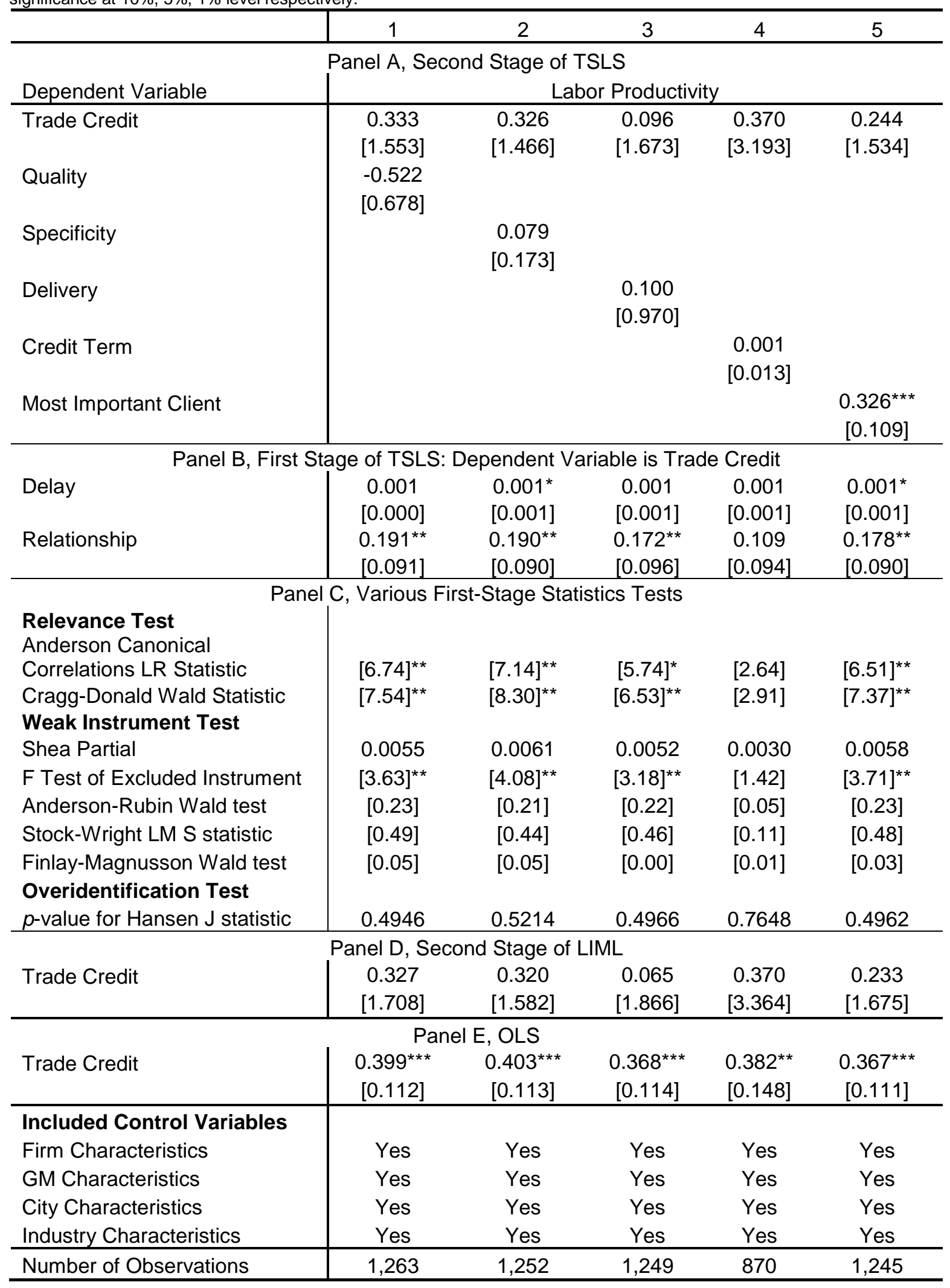


Table 8: Outliers

Note: Robust standard errors, clustered at industry-city level, are presented in the round bracket. *, ** ${ }^{* * *}$ represent significance at $10 \%, 5 \%, 1 \%$ level respectively.

\begin{tabular}{|c|c|c|c|}
\hline & 1 & 2 & 3 \\
\hline \multicolumn{4}{|c|}{ Panel A, Second Stage of TSLS } \\
\hline Dependent Variable & Labor Productivity & ROA & Firm Size \\
\hline Trade Credit & $\begin{array}{c}1.295 \\
{[1.203]} \\
\end{array}$ & $\begin{array}{c}0.064 \\
{[0.568]} \\
\end{array}$ & $\begin{array}{c}0.652 \\
{[1.572]} \\
\end{array}$ \\
\hline \multicolumn{4}{|c|}{ Panel B, First Stage of TSLS: Dependent Variable is Trade Credit } \\
\hline Delay & $\begin{array}{c}0.001 \\
{[0.001]}\end{array}$ & $\begin{array}{l}0.001^{*} \\
{[0.001]}\end{array}$ & $\begin{array}{l}0.001^{*} \\
{[0.001]}\end{array}$ \\
\hline Relationship & $\begin{array}{l}0.211^{* *} \\
{[0.091]}\end{array}$ & $\begin{array}{l}0.184^{\star *} \\
{[0.089]}\end{array}$ & $\begin{array}{l}0.186^{\star \star} \\
{[0.090]}\end{array}$ \\
\hline \\
\hline \multicolumn{4}{|c|}{ Panel C, Various First-Stage Statistics Tests } \\
\hline Anderson Canonical Correlations LR Statistic & {$[7.06]^{\star \star}$} & {$[6.23]^{\star \star}$} & {$[6.36]^{\star \star}$} \\
\hline Cragg-Donald Wald Statistic & {$[8.50]^{\star \star}$} & {$[7.17]^{\star \star}$} & {$[7.31]^{\star \star}$} \\
\hline Weak Instrument Test & & & \\
\hline Shea Partial & 0.0067 & 0.0059 & 0.0061 \\
\hline F Test of Excluded Instrument & {$[4.37]^{\star \star}$} & {$[3.84]^{\star \star}$} & {$[3.87]^{\star \star}$} \\
\hline Anderson-Rubin Wald test & {$[0.66]$} & {$[0.41]$} & {$[0.27]$} \\
\hline Stock-Wright LM S statistic & [1.25] & [0.83] & {$[0.58]$} \\
\hline Finlay-Magnusson Wald test & {$[1.16]$} & {$[0.01]$} & {$[0.17]$} \\
\hline \multicolumn{4}{|l|}{ Overidentification Test } \\
\hline$p$-value for Hansen $\mathrm{J}$ statistic & 0.8609 & 0.4005 & 0.5226 \\
\hline \multicolumn{4}{|c|}{ Panel D, Second Stage of LIML } \\
\hline Trade Credit & $\begin{array}{c}1.300 \\
{[1.210]}\end{array}$ & $\begin{array}{c}0.064 \\
{[0.578]}\end{array}$ & $\begin{array}{c}0.667 \\
{[1.696]}\end{array}$ \\
\hline \multicolumn{4}{|c|}{ Panel E, OLS } \\
\hline Trade Credit & $\begin{array}{c}0.417^{\star \star \star} \\
{[0.094]}\end{array}$ & $\begin{array}{c}0.056 \\
{[0.052]}\end{array}$ & $\begin{array}{c}0.467^{\star \star \star} \\
{[0.108]}\end{array}$ \\
\hline \multicolumn{4}{|l|}{ Included Control Variables } \\
\hline Firm Characteristics & Yes & Yes & Yes \\
\hline GM Characteristics & Yes & Yes & Yes \\
\hline City Characteristics & Yes & Yes & Yes \\
\hline Industry Characteristics & Yes & Yes & Yes \\
\hline Number of Observations & 1,248 & 1,265 & 1,260 \\
\hline
\end{tabular}


Table 9: Financially-constrained Firms

\begin{tabular}{|c|c|c|c|c|c|c|}
\hline & 1 & 2 & 3 & 4 & 5 & 6 \\
\hline & \multicolumn{3}{|c|}{ Financially-constrained firms } & \multicolumn{3}{|c|}{ Financially-unconstrained firms } \\
\hline \multicolumn{7}{|c|}{ Panel A, Second Stage of TSLS } \\
\hline Dependent Variable & $\begin{array}{c}\text { Labor } \\
\text { Productivity }\end{array}$ & ROA & $\begin{array}{l}\text { Firm } \\
\text { Size }\end{array}$ & $\begin{array}{c}\text { Labor } \\
\text { Productivity }\end{array}$ & ROA & $\begin{array}{l}\text { Firm } \\
\text { Size }\end{array}$ \\
\hline Trade Credit & $\begin{array}{c}-0.29 \\
{[1.219]}\end{array}$ & $\begin{array}{c}0.824 \\
{[1.272]}\end{array}$ & $\begin{array}{l}-0.264 \\
{[1.206]}\end{array}$ & $\begin{array}{c}1.697 \\
{[2.287]}\end{array}$ & $\begin{array}{l}-1.673 \\
{[1.760]}\end{array}$ & $\begin{array}{r}0.346 \\
{[0.787]}\end{array}$ \\
\hline \multicolumn{7}{|c|}{ Panel B, First Stage of TSLS: Dependent Variable is Trade Credit } \\
\hline Delay & $\begin{array}{c}0.001 \\
{[0.001]}\end{array}$ & $\begin{array}{c}0.001 \\
{[0.001]}\end{array}$ & $\begin{array}{c}0.001 \\
{[0.001]}\end{array}$ & $\begin{array}{c}0.001 \\
{[0.001]}\end{array}$ & $\begin{array}{c}0.001 \\
{[0.001]}\end{array}$ & $\begin{array}{c}0.001 \\
{[0.001]}\end{array}$ \\
\hline Relationship & $\begin{array}{l}0.304^{\star \star \star} \\
{[0.110]}\end{array}$ & $\begin{array}{c}0.299^{\star * \star} \\
{[0.109]}\end{array}$ & $\begin{array}{c}0.304^{\star \star \star} \\
{[0.110]}\end{array}$ & $\begin{array}{c}0.132 \\
{[0.117]}\end{array}$ & $\begin{array}{c}0.126 \\
{[0.117]}\end{array}$ & $\begin{array}{c}0.132 \\
{[0.117]}\end{array}$ \\
\hline \multicolumn{7}{|c|}{ Panel C, Various First-Stage Statistics Tests } \\
\hline \multicolumn{7}{|l|}{ Relevance Test } \\
\hline Anderson Canonical Correlations LR Statistic & {$[6.35]^{\star \star}$} & {$[6.29]^{\star \star}$} & {$[6.35]^{\star \star}$} & {$[2.66]$} & {$[2.37]$} & [2.66] \\
\hline $\begin{array}{l}\text { Cragg-Donald Wald Statistic } \\
\text { Weak Instrument Test }\end{array}$ & {$[10.14]^{\star \star \star}$} & {$[9.99]^{\star \star \star}$} & {$[10.14]^{\star \star}$} & [3.23] & {$[2.81]$} & [3.23] \\
\hline Shea Partial & 0.0098 & 0.0097 & 0.0098 & 0.2239 & 0.2709 & 0.2239 \\
\hline F Test of Excluded Instrument & {$[5.00]^{\star \star \star}$} & {$[4.91]^{\star \star \star}$} & {$[5.00]^{\star \star \star}$} & [1.52] & [1.32] & {$[1.52]$} \\
\hline Anderson-Rubin Wald test & [0.08] & {$[0.25]$} & {$[0.04]$} & [2.01] & {$[0.79]$} & {$[0.16]$} \\
\hline Stock-Wright LM S statistic & {$[0.15]$} & [0.53] & {$[0.07]$} & [3.04] & [1.83] & [0.35] \\
\hline Finlay-Magnusson Wald test & {$[0.06]$} & {$[0.42]$} & {$[0.05]$} & {$[0.55]$} & [0.90] & [0.19] \\
\hline \multicolumn{7}{|l|}{ Overidentification Test } \\
\hline$p$-value for Hansen $\mathrm{J}$ statistic & 0.7029 & 0.5011 & 0.9697 & 0.1910 & 0.5533 & 0.5738 \\
\hline \multicolumn{7}{|c|}{ Panel D, Second Stage of LIML } \\
\hline Trade Credit & -0.306 & 0.844 & -0.264 & 3.507 & -1.772 & 0.382 \\
\hline
\end{tabular}




\begin{tabular}{l|ccc|ccc} 
& {$[1.249]$} & {$[1.316]$} & {$[1.206]$} & {$[6.455]$} & {$[1.897]$} & {$[0.911]$} \\
\hline \multirow{2}{*}{ Trade Credit } & \multicolumn{2}{|c|}{ Panel E, OLS } & & & & \\
& $0.324^{* *}$ & 0.188 & $0.356^{* *}$ & $0.475^{* * *}$ & 0.149 & 0.103 \\
& {$[0.135]$} & {$[0.169]$} & {$[0.147]$} & {$[0.158]$} & {$[0.116]$} & {$[0.063]$} \\
\hline Included Control Variables & & & & & & \\
Firm Characteristics & Yes & Yes & Yes & Yes & Yes & Yes \\
GM Characteristics & Yes & Yes & Yes & Yes & Yes & Yes \\
City Characteristics & Yes & Yes & Yes & Yes & Yes & Yes \\
Industry Characteristics & Yes & Yes & Yes & Yes & Yes & Yes \\
\hline Number of Observations & 665 & 660 & 665 & 600 & 592 & 600 \\
\hline
\end{tabular}


Table 10: Buyer Credit

Note: Robust standard errors, clustered at industry-city level, are presented in the round bracket. * ${ }^{* \star},{ }^{* \star *}$ represent significance at $10 \%, 5 \%, 1 \%$ level respectively.

\begin{tabular}{|c|c|c|c|}
\hline & 1 & 2 & 3 \\
\hline \multicolumn{4}{|c|}{ Panel A, Second Stage of TSLS } \\
\hline Dependent Variable & Labor Productivity & ROA & Firm Size \\
\hline Trade Credit & $\begin{array}{c}0.364 \\
{[1.517]}\end{array}$ & $\begin{array}{c}0.059 \\
{[1.124]}\end{array}$ & $\begin{array}{c}0.700 \\
{[1.590]}\end{array}$ \\
\hline Buyer Credit & $\begin{array}{l}-0.091 \\
{[0.164]} \\
\end{array}$ & $\begin{array}{c}-0.06 \\
{[0.094]}\end{array}$ & $\begin{array}{l}-0.175 \\
{[0.185]}\end{array}$ \\
\hline \multicolumn{4}{|c|}{ Panel B, First Stage of TSLS: Dependent Variable is Trade Credit } \\
\hline Delay & $\begin{array}{l}0.001^{*} \\
{[0.001]}\end{array}$ & $\begin{array}{l}0.001^{*} \\
{[0.001]}\end{array}$ & $\begin{array}{l}0.001^{*} \\
{[0.001]}\end{array}$ \\
\hline Relationship & $\begin{array}{l}0.179^{\star *} \\
{[0.090]} \\
\end{array}$ & $\begin{array}{l}0.176^{\star *} \\
{[0.090]}\end{array}$ & $\begin{array}{l}0.179^{* *} \\
{[0.090]}\end{array}$ \\
\hline \multicolumn{4}{|c|}{ Panel C, Various First-Stage Statistics Tests } \\
\hline Relevance Test & & & \\
\hline Anderson Canonical Correlations LR Statistic & {$[6.33]^{\star \star}$} & {$[6.18]^{\star \star}$} & {$[6.33]^{\star \star}$} \\
\hline $\begin{array}{l}\text { Cragg-Donald Wald Statistic } \\
\text { Weak Instrument Test }\end{array}$ & {$[7.23]^{\star \star}$} & {$[7.05]^{\star *}$} & {$[7.23]^{\star *}$} \\
\hline Shea Partial & 0.0060 & 0.0059 & 0.0060 \\
\hline F Test of Excluded Instrument & {$[3.82]^{\star *}$} & {$[3.72]^{\star \star}$} & {$[3.82]^{\star \star}$} \\
\hline Anderson-Rubin Wald test & {$[0.15]$} & {$[0.01]$} & {$[0.24]$} \\
\hline Stock-Wright LM S statistic & {$[0.31]$} & {$[0.02]$} & {$[0.52]$} \\
\hline Finlay-Magnusson Wald test & {$[0.06]$} & {$[0.00]$} & {$[0.19]$} \\
\hline Overidentification Test & & & \\
\hline$p$-value for Hansen J statistic & 0.6010 & 0.9626 & 0.5610 \\
\hline \multicolumn{4}{|c|}{ Panel D, Second Stage of LIML } \\
\hline Trade Credit & $\begin{array}{c}0.363 \\
{[1.596]}\end{array}$ & $\begin{array}{c}0.059 \\
{[1.124]}\end{array}$ & $\begin{array}{c}0.714 \\
{[1.686]}\end{array}$ \\
\hline \multicolumn{4}{|c|}{ Panel E, OLS } \\
\hline Trade Credit & $\begin{array}{c}0.391^{\star \star *} \\
{[0.113]}\end{array}$ & $\begin{array}{l}0.170^{\star} \\
{[0.087]}\end{array}$ & $\begin{array}{c}0.467^{\star \star \star} \\
{[0.113]}\end{array}$ \\
\hline \multicolumn{4}{|l|}{ Included Control Variables } \\
\hline Firm Characteristics & Yes & Yes & Yes \\
\hline GM Characteristics & Yes & Yes & Yes \\
\hline City Characteristics & Yes & Yes & Yes \\
\hline Industry Characteristics & Yes & Yes & Yes \\
\hline Number of Observations & 1,254 & 1,241 & 1,254 \\
\hline
\end{tabular}


Table 11: Disruption Effect

Note: Robust standard errors, clustered at industry-city level, are presented in the round bracket. * ${ }^{* \star}$, ${ }^{\star \star *}$ represent significance at $10 \%, 5 \%, 1 \%$ level respectively.

\begin{tabular}{l|c}
\hline Dependent Variable & Capacity Utilization \\
\hline Trade Credit & 0.251 \\
& {$[0.170]$} \\
\hline Delay & 0.001 \\
Relationship & {$[0.001]$} \\
& $0.219^{\star \star}$ \\
\hline Relevance Test & {$[0.090]$} \\
Anderson Canonical Correlations LR Statistic & {$[7.62]^{\star \star}$} \\
Cragg-Donald Wald Statistic & {$[9.41]^{\star \star \star}$} \\
Weak Instrument Test & \\
Shea Partial & 0.0068 \\
F Test of Excluded Instrument & {$[4.76]^{\star \star}$} \\
Anderson-Rubin Wald test & {$[2.11]$} \\
Stock-Wright LM S statistic & {$[3.81]$} \\
Finlay-Magnusson Wald test & {$[2.16]$} \\
Overidentification Test & \\
$p$-value for Hansen J statistic & 0.6442 \\
\hline Trade Credit & 0.257 \\
& {$[0.176]$} \\
\hline Trade Credit & $0.036^{\star \star \star}$ \\
& {$[0.013]$} \\
\hline Included Control Variables & \\
Firm Characteristics & Yes \\
GM Characteristics & Yes \\
City Characteristics & Yes \\
Industry Characteristics & Yes \\
\hline Number of Observations & 1,169 \\
\hline
\end{tabular}


Table 12: Monitoring Effect

\begin{tabular}{|c|c|c|c|c|c|c|}
\hline & \multicolumn{3}{|c|}{ With monitoring difficulty } & \multicolumn{3}{|c|}{ Without monitoring difficulty } \\
\hline \multicolumn{7}{|c|}{ Panel A, Second Stage of TSLS } \\
\hline Dependent Variable & $\begin{array}{l}\text { Labor } \\
\text { Productivity }\end{array}$ & ROA & Firm Size & $\begin{array}{l}\text { Labor } \\
\text { Productivity }\end{array}$ & ROA & $\begin{array}{l}\text { Firm } \\
\text { Size }\end{array}$ \\
\hline \multirow[t]{2}{*}{ Trade Credit } & $2.522^{\star \star \star}$ & 2.342 & 0.113 & -1.818 & -1.904 & 1.169 \\
\hline & {$[0.713]$} & [1.819] & {$[0.217]$} & [3.653] & [1.844] & [1.447] \\
\hline \multicolumn{7}{|c|}{ Panel B, First Stage of TSLS: Dependent Variable is Trade Credit } \\
\hline \multirow[t]{2}{*}{ Delay } & $0.003^{\star * \star}$ & $0.003^{\star \star \star}$ & $0.003^{\star \star \star}$ & 0.000 & 0.000 & 0.000 \\
\hline & {$[0.001]$} & {$[0.001]$} & {$[0.001]$} & {$[0.000]$} & {$[0.000]$} & {$[0.001]$} \\
\hline \multirow[t]{2}{*}{ Relationship } & 0.354 & 0.354 & 0.354 & 0.109 & 0.106 & 0.109 \\
\hline & {$[0.224]$} & {$[0.223]$} & {$[0.224]$} & {$[0.089]$} & {$[0.089]$} & {$[0.089]$} \\
\hline \multicolumn{7}{|c|}{ Panel C, Various First-Stage Statistics Tests } \\
\hline \multicolumn{7}{|l|}{ Relevance Test } \\
\hline $\begin{array}{l}\text { Anderson Canonical Correlations LR } \\
\text { Statistic }\end{array}$ & {$[6.11]^{\star \star}$} & {$[6.12]^{\star \star}$} & {$[6.11]^{\star \star}$} & {$[2.07]$} & [1.88] & [2.12] \\
\hline Cragg-Donald Wald Statistic & {$[14.18]^{\star \star \star}$} & {$[14.06]^{\star \star \star}$} & {$[14.18]^{\star \star \star}$} & {$[0.74]$} & {$[0.67]$} & {$[0.75]$} \\
\hline \multicolumn{7}{|l|}{ Weak Instrument Test } \\
\hline Shea Partial & 0.0266 & 0.0266 & 0.0266 & 0.3305 & 0.3665 & 0.3222 \\
\hline F Test of Excluded Instrument & {$[7.88]^{\star \star \star}$} & {$[7.75]^{\star \star \star}$} & {$[7.88]^{\star \star \star}$} & {$[1.06]$} & {$[0.96]$} & {$[1.08]$} \\
\hline Anderson-Rubin Wald test & {$[6.16]^{\star \star \star}$} & {$[1.70]$} & {$[4.20]^{\star \star}$} & {$[0.13]$} & {$[0.99]$} & {$[0.58]$} \\
\hline Stock-Wright LM S statistic & {$[11.46]^{\star \star \star}$} & [3.45] & {$[7.08]^{\star \star}$} & {$[0.28]$} & [2.18] & {$[1.22]$} \\
\hline Finlay-Magnusson Wald test & {$[12.52]^{\star \star \star}$} & {$[1.66]$} & {$[8.37]^{\star \star \star}$} & {$[0.25]$} & {$[1.07]$} & {$[0.65]$} \\
\hline \multicolumn{7}{|l|}{ Overidentification Test } \\
\hline$p$-value for Hansen $\mathrm{J}$ statistic & 0.1043 & 0.9701 & 0.0085 & 0.9448 & 0.2579 & 0.8893 \\
\hline
\end{tabular}

Panel D, Second Stage of LIML 


\begin{tabular}{|c|c|c|c|c|c|c|}
\hline Trade Credit & $\begin{array}{c}2.724^{\star \star \star} \\
{[0.836]}\end{array}$ & $\begin{array}{c}2.342 \\
{[1.819]}\end{array}$ & $\begin{array}{c}0.122 \\
{[0.315]}\end{array}$ & $\begin{array}{l}-1.828 \\
{[3.672]}\end{array}$ & $\begin{array}{l}-2.755 \\
{[3.240]}\end{array}$ & $\begin{array}{c}1.18 \\
{[1.467]}\end{array}$ \\
\hline \multicolumn{7}{|c|}{ Panel E, OLS } \\
\hline Trade Credit & $\begin{array}{c}0.571^{\star \star \star} \\
{[0.200]}\end{array}$ & $\begin{array}{l}0.400^{*} \\
{[0.207]}\end{array}$ & $\begin{array}{l}0.093^{*} \\
{[0.055]}\end{array}$ & $\begin{array}{l}0.323^{\star \star} \\
{[0.129]}\end{array}$ & $\begin{array}{c}0.077 \\
{[0.105]}\end{array}$ & $\begin{array}{c}0.052 \\
{[0.043]}\end{array}$ \\
\hline \multicolumn{7}{|c|}{ Included Control Variables } \\
\hline Firm Characteristics & Yes & Yes & Yes & Yes & Yes & Yes \\
\hline GM Characteristics & Yes & Yes & Yes & Yes & Yes & Yes \\
\hline City Characteristics & Yes & Yes & Yes & Yes & Yes & Yes \\
\hline Industry Characteristics & Yes & Yes & Yes & Yes & Yes & Yes \\
\hline Number of Observations & 442 & 438 & 442 & 806 & 799 & 808 \\
\hline
\end{tabular}


Table 13: Growth Potential Effect

Note: Robust standard errors, clustered at industry-city level, are presented in the round bracket. *, **, ** represent significance at $10 \%, 5 \%, 1 \%$ level respectively.

\begin{tabular}{|c|c|c|c|c|c|c|}
\hline & 1 & 2 & 3 & 4 & 5 & 6 \\
\hline & \multicolumn{3}{|c|}{ OLS } & \multicolumn{3}{|c|}{ TSLS } \\
\hline Dependent Variable & Labor Productivity & ROA & Firm Size & Labor Productivity & ROA & Firm Size \\
\hline \multicolumn{7}{|c|}{ Panel A, With Controlling for Growth Potential } \\
\hline Trade Credit & $\begin{array}{c}0.382^{\star \star \star} \\
{[0.101]}\end{array}$ & $\begin{array}{l}0.172^{*} \\
{[0.092]}\end{array}$ & $\begin{array}{c}0.462^{\star \star \star} \\
{[0.100]}\end{array}$ & $\begin{array}{c}0.481 \\
{[1.714]}\end{array}$ & $\begin{array}{c}0.142 \\
{[1.282]}\end{array}$ & $\begin{array}{c}0.318 \\
{[0.521]}\end{array}$ \\
\hline Avg Annual Sales Growth Rate (Past 3 Yrs) & $\begin{array}{c}0.301^{\star \star \star} \\
{[0.091]}\end{array}$ & $\begin{array}{c}0.056 \\
{[0.049]}\end{array}$ & $\begin{array}{l}0.334^{\star \star \star} \\
{[0.100]}\end{array}$ & $\begin{array}{c}0.299^{\star * \star} \\
{[0.092]}\end{array}$ & $\begin{array}{c}0.056 \\
{[0.047]}\end{array}$ & $\begin{array}{l}0.032^{\star *} \\
{[0.015]}\end{array}$ \\
\hline \multicolumn{7}{|c|}{ Panel B, Without Controlling for Growth Potential } \\
\hline Trade Credit & $\begin{array}{c}0.394^{* * *} \\
{[0.105]}\end{array}$ & $\begin{array}{l}0.175^{*} \\
{[0.093]}\end{array}$ & $\begin{array}{c}0.476^{\star \star *} \\
{[0.106]}\end{array}$ & $\begin{array}{c}0.510 \\
{[1.719]}\end{array}$ & $\begin{array}{c}0.147 \\
{[1.278]}\end{array}$ & $\begin{array}{c}0.321 \\
{[0.516]}\end{array}$ \\
\hline \multicolumn{7}{|l|}{ Included Control Variables } \\
\hline Firm Characteristics & Yes & Yes & Yes & Yes & Yes & Yes \\
\hline GM Characteristics & Yes & Yes & Yes & Yes & Yes & Yes \\
\hline City Characteristics & Yes & Yes & Yes & Yes & Yes & Yes \\
\hline Industry Characteristics & Yes & Yes & Yes & Yes & Yes & Yes \\
\hline Number of Observations & 1,284 & 1,272 & 1,284 & 1,228 & 1,216 & 1,228 \\
\hline
\end{tabular}


Appendix: The survey questions regarding the key variables

\begin{tabular}{|c|c|}
\hline Variable & Survey Question \\
\hline Trade Credit & $\begin{array}{l}\text { Question F8: \% of inputs (from this supplier) you buy on } \\
\text { credit }\end{array}$ \\
\hline Delay & $\begin{array}{l}\text { Question F9: If your main supplier of your } 2 \text { major inputs } \\
\text { failed to deliver, how long would it take you to obtain } \\
\text { replacement supplies? }\end{array}$ \\
\hline Relationship & $\begin{array}{l}\text { Question F10: Do friends and relatives of the owners of } \\
\text { your plant own any of the suppliers of your plant's most } \\
\text { important production materials? }\end{array}$ \\
\hline Bank Loan & $\begin{array}{l}\text { Question L2: Do you have a loan from a bank or } \\
\text { financial institution? }\end{array}$ \\
\hline Government Representative in the & Question M7: Is the government (including state \\
\hline Education & $\begin{array}{l}\text { Question M1: What is the highest level of education } \\
\text { completed by the General Manager? }\end{array}$ \\
\hline Years of Being GM & $\begin{array}{l}\text { Question M3: How many years has the General } \\
\text { Manager held this position? }\end{array}$ \\
\hline Depute GM Before & $\begin{array}{l}\text { Question M3: Before becoming General manager in this } \\
\text { firm, what was his/her position? }\end{array}$ \\
\hline Government Cadre & $\begin{array}{l}\text { Question M3: Before becoming General manager in this } \\
\text { firm, what was his/her position? }\end{array}$ \\
\hline Party Membership & $\begin{array}{l}\text { Question M4: What's the position of the General } \\
\text { Manager in the party? }\end{array}$ \\
\hline Government Appointment & $\begin{array}{l}\text { Question M6: How was the General Manager } \\
\text { appointed? }\end{array}$ \\
\hline Quality & $\begin{array}{l}\text { Question F11: What percentage of supplies you } \\
\text { purchase are lower than expected quality? }\end{array}$ \\
\hline Specificity & $\begin{array}{l}\text { Question F7: Is this input made to your unique } \\
\text { specification? }\end{array}$ \\
\hline Delivery & $\begin{array}{l}\text { Question F16: What percentage of sales in the last year } \\
\text { was lost due to delivery delays from suppliers? }\end{array}$ \\
\hline Credit Term & $\begin{array}{l}\text { Question L14: Regarding the repayment of trade credit } \\
\text { (average over all your trade creditors for all inputs), } \\
\text { average number of days before supplier will impose } \\
\text { penalties }\end{array}$ \\
\hline Most Important Client & $\begin{array}{l}\text { Question F8: Is your firm the most important customer of } \\
\text { this supplier? }\end{array}$ \\
\hline
\end{tabular}

